\title{
A tunable diode laser absorption spectrometer for formaldehyde atmospheric measurements validated by simulation chamber instrumentation
}

\author{
V. Catoire ${ }^{1 *}$, F. Bernard ${ }^{2}$, Y. Mébarki ${ }^{1}$, A. Mellouki ${ }^{2}$, G. Eyglunent $^{2}$, V. Daële ${ }^{2}$, C. \\ Robert $^{1}$
}

1. Laboratoire de Physique et Chimie de l'Environnement et de l'Espace (LPC2E), CNRSUniversité d'Orléans (UMR 6115), Observatoire des Sciences de l'Univers en région Centre (OSUC) , 3A Avenue de la Recherche Scientifique, 45071 Orléans Cedex 2, France

2. Institut de Combustion, Aérothermique, Réactivité et Environnement (ICARE), CNRS (UPR 3021), Observatoire des Sciences de l'Univers en région Centre (OSUC), 1C Avenue de la Recherche Scientifique, 45071 Orléans Cedex 2, France

* Corresponding author. Email: Valery.Catoire@cnrs-orleans.fr

\begin{abstract}
A tunable diode laser absorption spectrometer (TDLAS) for formaldehyde atmospheric measurements has been set up and validated through comparison experiments with a Fourier transform infrared spectrometer (FTIR) in a simulation chamber. Formaldehyde was generated in situ in the chamber from reaction of ethene with ozone. Three HCHO rovibrational line intensities (at 2909.71, 2912.09 and $2914.46 \mathrm{~cm}^{-1}$ ) possibly used by TDLAS were calibrated by FTIR spectra simultaneously recorded in the $1600-3200 \mathrm{~cm}^{-1}$ domain during ethene ozonolysis, enabling the on-line deduction of the varying concentration for $\mathrm{HCHO}$ in formation. The experimental line intensities values inferred confirmed the calculated ones from the updated HITRAN database (Rothman et al., 2009, based on Perrin et al., 2009). In addition, the feasibility of stratospheric in situ HCHO measurements using the $2912.09 \mathrm{~cm}^{-1}$ line was demonstrated. The TDLAS performances were also assessed, leading to a $2 \sigma$ detection limit of $88 \mathrm{ppt}$ in volume mixing ratio with a response time of $60 \mathrm{~s}$ at 30 Torr and $294 \mathrm{~K}$ for $112 \mathrm{~m}$ optical path. As part of this work, the room-temperature rate
\end{abstract}


constant of this reaction and the $\mathrm{HCHO}$ formation yield were found to be in excellent agreement with the compiled literature data.

Keywords: formaldehyde, ethene ozonolysis, in situ measurements, stratosphere, simulation chamber, infrared tunable diode laser absorption spectrometry (TDLAS), Fourier Transform Infrared spectrometry (FTIR).

\section{Introduction}

Formaldehyde plays a key role in the odd hydrogen family $\left(\mathrm{HO}_{\mathrm{x}}=\mathrm{OH}+\mathrm{HO}_{2}\right)$ chemistry, with its subsequent involvement in $\mathrm{HO}_{2}$ production (Seinfeld and Pandis, 2006). The largest sources of tropospheric HCHO come from the oxidation of methane $\left(\mathrm{CH}_{4}\right)$ and other nonmethane volatile organic compounds (VOCs), which have both natural and anthropogenic origins (Anderson et al., 1996). Biomass burning, incomplete combustion, emissions from industries and vegetation represent the main direct emission sources (Carlier et al., 1986; Lee et al., 1998). The main loss processes include photolysis by ultraviolet (UV) radiation and oxidation by $\mathrm{OH}$ radicals. Formaldehyde removal can also take place through dry deposition, heterogeneous loss on aerosol particles (Tie et al., 2001), cloud chemistry and precipitation scavenging (e.g., Lelieveld and Crutzen, 1990; Heikes, 1992). HCHO has its greatest mixing ratio in the boundary layer, near its emission sources. Its abundance decreases with altitude up to the upper troposphere, where it can reach values as low as a few tens of ppt in volume mixing ratios (Dufour et al., 2009). The lifetime of formaldehyde regarding the major chemical and physical removal pathways is of the order of a few hours in the troposphere (Possanzini et al., 2002). In the upper troposphere, $\mathrm{HCHO}$ is found to be a relevant indicator for testing the presence of additional $\mathrm{HO}_{\mathrm{x}}$ precursor species possibly moved upward by convective transport (Crawford et al., 1999). In the stratosphere, the abundance of HCHO 
increases with altitude, mainly as a result of the oxidation of methane by $O H$ and $O\left({ }^{1} D\right)$, resulting in a "C-shaped" vertical profile from the troposphere to the stratosphere (Barth et al., 2007).

Formaldehyde concentrations have never been measured in situ in the stratosphere. Up to now, only three remote vertically resolved satellite measurements of HCHO have been reported, one by SMR (Sub-Millimeter Radiometer) aboard Odin satellite (Ricaud et al., 2007 ) in the upper stratosphere ( $>35 \mathrm{~km}$ altitude), and the other ones by MIPAS (Michelson Interferometer for Passive Atmospheric Sounding) aboard Envisat (Steck et al., 2008) and by FTS (Fourier Transform Spectrometer) aboard ACE-SCISAT (Coheur et al., 2007; Dufour et al., 2009). Whereas the MIPAS measurements are performed using several spectral microwindows in the $5.7 \mu \mathrm{m}$ region (i.e., the $\nu_{2}$ band centred at $1746 \mathrm{~cm}^{-1}$ ), the FTS measurements use the $3.6 \mu \mathrm{m}$ region (i.e., around $2600-3100 \mathrm{~cm}^{-1}$ ). Formaldehyde indeed shows strong $v_{1}$ and $v_{5}$ fundamental vibration bands centred at 2782 and $2844 \mathrm{~cm}^{-1}$, respectively.

TDLAS (Tunable Diode Laser Absorption Spectrometry) measurements of HCHO in the upper troposphere aboard aircrafts have been pioneered by Fried and co-workers using the $2831.64 \mathrm{~cm}^{-1}$ ro-vibrational line of the $v_{5}$ band (Fried et al., 2008, and references therein). SPIRALE (SPectroscopie Infra Rouge par Absorption de Lasers Embarqués) is a balloonborne instrument using the TDLAS method for simultaneous in situ measurements of numerous trace gases (e.g., $\mathrm{O}_{3}, \mathrm{CH}_{4}, \mathrm{CO}, \mathrm{OCS}, \mathrm{N}_{2} \mathrm{O}, \mathrm{HNO}_{3}, \mathrm{NO}_{2}, \mathrm{NO}, \mathrm{HCl}, \mathrm{COF}_{2}, \mathrm{H}_{2} \mathrm{O}_{2}$ ) with a high vertical resolution $(\sim 5 \mathrm{~m})$ (Moreau et al., 2005) in the upper troposphere and the stratosphere. SPIRALE measurements have been used for dynamics and chemistry studies (see e.g., Berthet et al., 2006; Huret et al., 2006; Berthet et al., 2007; Müller et al., 2007; Pirre et al., 2008; Mébarki et al., 2010), as well as for validation of stratospheric species abundances measured by satellite instruments such as Envisat MIPAS and GOMOS (Global Ozone Measurement by the Occultation of Stars), ACE-SCISAT FTS and Odin SMR (see e.g., Wang et al., 2007; Renard et al., 2008; Strong et al., 2008; Jégou et al., 2008). One of the six SPIRALE lasers can now operate in the R-branch most intense lines of the $v_{5}$ band, with three emission modes included between 2909 and $2915 \mathrm{~cm}^{-1}$, which opens possibility for field measurements.

Several spectroscopic studies have reported line parameters for the $v_{5}$ band, but with intensities in disagreement with each other by up to a factor of three (Rothman at al., 2005, Herndon et al., 2005, Perrin et al., 2006, Perrin et al., 2009). The study of Perrin et al. (2009) 
recently identified the reasons of the discrepancies and has been included into the new HITRAN database (Rothman at al., 2009). The existence of numerous overtones and combination bands has sometimes led to inconsistencies in blended or degenerate doublet lines. This study derived a consistent set of line intensity parameters for both the 3.6 and 5.7 $\mu \mathrm{m}$ bands, based on some FTIR (Fourier Transform Infra Red) lines measurements covering the whole domain (1600-3200 $\left.\mathrm{cm}^{-1}\right)$ and on theoretical spectroscopy calculations. However, this study is the first one delivering consistent values, which needs confirmation, all the more so as two of the three line intensities in the range $2909-2915 \mathrm{~cm}^{-1}$ were not directly measured.

The first goal of the present study is to determine the absolute intensity of these specific lines in order to allow for deriving reliable stratospheric $\mathrm{HCHO}$ concentrations using airborne or balloon-borne instruments such as SPIRALE. Our line calibrations were performed using FTIR spectra covering the whole region (around 1600-3200 $\mathrm{cm}^{-1}$ ) simultaneously recorded in an atmospheric simulation chamber, and hence with consistent values between both bands. The well-known chemical reaction system of ethene ozonolysis was used as source of formaldehyde. Given this compound is sticky and polymerizable, its concentration determination is rather challenging (Gratien et al., 2007; Brauers et al., 2007; Perrin et al., 2009). In the present study, HCHO was thus produced in situ, which has the great advantage to lead to low and so, accurate concentrations, since no polymerization and wall adsorption was expected. The second goal of the study is to evaluate the interest of implementing TDLAS instrumentation in the simulation chamber of ICARE-Orléans. The conventional methods currently used for laboratory measurements of formaldehyde are limited in detection limit ( $>50 \mathrm{ppt}$ in volume mixing ratio units) and/or in measurement frequency ( $>1 \mathrm{~min})$ (Hak et al., 2005; Wisthaler et al., 2008; Hottle et al., 2009; Jobson and McCoskey, 2010). TDLAS method is expected to be at least as sensitive, and is known to perform rapid on-line measurements (in a few seconds), which is the main reason for its use aboard mobile instruments such as airborne or balloon-borne spectrometers. In the case of static measurements performed in laboratory simulation chambers, the very short response time should allow for lowering the detection limit and improving the accuracy of the kinetics and mechanistic studies. The well-established reaction of ethene with ozone has been used in the present work to test the TDLAS potentiality with respect to the already existing chamber instrumentation. 


\section{Experimental}

\subsection{The Atmospheric Simulation Chamber}

Experiments were carried out in the 7300 L ICARE indoor atmospheric simulation made of Fluorene-Ethene-Propene (FEP) foil (DuPont) with a parallelepiped shape. The experiments were performed at $294 \pm 1 \mathrm{~K}$ in dry purified air (relative humidity, $\mathrm{RH}<2 \%$ ). The chamber was operated at $\sim 0.08$ Torr above the atmospheric pressure in order to avoid external contamination and to compensate the sampling flows of the various instruments connected to the chamber. This was achieved during the experiments by continuously adding 5 to $20 \mathrm{~L}$ $\min ^{-1}$ of purified air. Between experiments, the chamber was cleaned by flushing it with purified air at a flow rate of $\sim 100 \mathrm{~L} \mathrm{~min}^{-1}$ for at least $12 \mathrm{~h}$. A fan made of Teflon insured homogeneous mixing of the reactant within $\sim 1 \mathrm{~min}$.

Temperature and relative humidity were monitored by a combined sensor (T870 Series T800, Dostmann electronic) and the differential pressure was measured using an MKS gauge (0-10 Torr range). The chamber is equipped with an in situ FTIR spectrometer (Nicolet 5700 Magna) coupled to a White-type multipass cell resulting in an optical path length of 166 $\mathrm{m}$. $\mathrm{HgCdTe} / \mathrm{B}$ semiconductor was used as detector and cooled with liquid nitrogen at a temperature close to $77 \mathrm{~K}$. The instrument was operated in the mid-IR region, from 4000 to $600 \mathrm{~cm}^{-1}$. The IR spectra were recorded every $4 \mathrm{~min} 15 \mathrm{~s}$ by co-adding 110 interferograms with a resolution of $1 \mathrm{~cm}^{-1}$, using Happ-Genzel apodization. IR spectra acquisition was operated using OMNIC software (OMNIC, Thermo Electron Corporation, version 6.2). Reactants (ethene and ozone) and products were monitored during the course of the reaction and their concentrations were determined using calibrated reference spectra. The chamber is also equipped with gas monitors for ozone (Horiba, APOA-360) and $\mathrm{NO}, \mathrm{NO}_{2}$ and $\mathrm{NO}_{\mathrm{x}}$ (Horiba, APNA-360), which enabled to measure the $\mathrm{O}_{3}$ concentration and any $\mathrm{NO}_{\mathrm{x}}$ background during the experiments. Ozone was generated from an electric discharge in an oxygen flow of $2 \mathrm{~L} \mathrm{~min}^{-1}$ capable of fast introduction into the chamber, which enables to reach the desired concentration in few minutes. Known amounts of the $\mathrm{C}_{2} \mathrm{H}_{4}$ and $\mathrm{SF}_{6}$ were introduced into the chamber using a calibrated $0.9 \mathrm{~L}$ cylinder equipped with two pressure gauges (0-10 Torr and 0-1000 Torr, MKS Baratron). All experiments presented here were conducted in the dark. 
Dilution and leak rates were determined before the start of each experiment by monitoring the decay of added amount of $\mathrm{SF}_{6}$ (190 ppb volume mixing ratio) using the IR band $\left(948 \mathrm{~cm}^{-1}\right)$. This decay rate was found to be in the range $(1-4) \times 10^{-5} \mathrm{~s}^{-1}$ depending on the experimental conditions (added flow during the runs). Ozone was injected before adding ethene, in order to estimate its total loss rate. This one was found to be slightly higher than that of $\mathrm{SF}_{6}\left(\sim 2.6-7.9 \times 10^{-5} \mathrm{~s}^{-1}\right)$. Ethene loss rate, determined in independent runs, was found to be similar to that of $\mathrm{SF}_{6}$. Before each experiment, background concentrations in the chamber were checked systematically and found to be lower than the detection limits (e. g., $\left.\left[\mathrm{NO}_{\mathrm{x}}\right]<1 \mathrm{ppb},\left[\mathrm{O}_{3}\right]<1 \mathrm{ppb}\right)$.

\subsection{The Tunable Diode Laser Absorption Spectrometer (TDLAS)}

Gas mixture samples from the simulation chamber were continuously collected via a PFA Teflon tube (6 mm o.d.) and passed through the TDLAS multipass absorption cell, with a controlled flow of $3.0 \mathrm{~L} \mathrm{~min}^{-1}$, using a scroll pump (XDS10 Boc Edwards). It is known that loss of HCHO in the sampling line made of Teflon is not significant (Wert et al., 2002; Herndon et al., 2007). This has been verified by observing no concentration change in the TDLAS cell when the tube length was varied by a factor of two. The pressure cell was around 30 Torr, precisely known ( \pm 0.1 Torr) using a 0-100 Torr range gauge (MKS Baratron), and maintained constant by tuning a simple valve located at the cell output, upstream of the pump. This pressure reduction enabled the cell content to be completely renewed in less than $4 \mathrm{~s}$, which allows for high frequency measurements. The low pressure also allows for the trace gas species ro-vibrational lines broadening to be reduced, so that the molecular lines were clearly distinguished and the baseline (i.e. the laser signal without absorption) was easily interpolated, which improves the measurement accuracy and the sensitivity.

The multiple reflection absorption cell used in this work has been already described in detail elsewhere (Robert, 2007). In brief, it consists of three spherical mirrors as in a White cell but its principle is different. It behaves as a multiplier of a Herriott cell from which it inherits the opto-mechanical stability qualities. The Herriott cell and the White cell are two particular cases of this type of cell. The main advantages of this cell are that it is made of standard mirrors, it is easily set up and tuned for adjusting the path length (by rotation of only one mirror), and it is compact, while allowing a great number of reflections and thus a large optical path (potentially more than $280 \mathrm{~m}$ ). In the configuration used in the present 
experiments, the total optical path length was $112.3 \mathrm{~m}$, determined by counting the visible spots of a laser diode (He-Ne) on the mirrors before the measurements. The three mirrors are of equal curvature (with a radius of $2500 \mathrm{~mm}$ ) and the separation between the opposite ones is $1.08 \mathrm{~m}$. The mirror coating is protecting gold, with an effective reflection coefficient of $98 \%$ in the present case, which restricted the path length to the above value. The mirrors are set in the hermetically sealed cell with two windows (ZnSe wedge) for the input/output laser beam passing.

The acquisition and detection systems are from SPIRALE instrument, already described in detail (Moreau et al., 2005) and therefore summarized hereafter. A lead-salt laser diode (Laser Components Instruments Group) produced several pure single mode radiations of typically less than $1 \mathrm{~mW}$ power. The three modes selected for the present study emitted in the spectral micro-windows 2909.2-2909.9, 2911.8-2912.2, and 2914.1-2914.8 $\mathrm{cm}^{-1}$, inferred from reference spectra of pure gaseous carbonyl sulphide (OCS) provided by a commercial cylinder. The relative spectral scale is determined by the use of a Fabry-Pérot interferometer, as previously reported (Moreau et al. 2005; Joly et al., 2008). Mode purity was checked by observing that null optical transmission from saturated lines of concentrated OCS contained in an external small cell and the laser switching-off give equal electrical signals. Cooling the laser at 96.6-97.1 K using liquid nitrogen and applying a current of typically 305-310 mA enabled emission at the selected wavenumber regions. The spectral windows were swept by applying an asymmetric saw-tooth ramp of about $30 \mathrm{~mA}$ at $\sim 200 \mathrm{~Hz}$ frequency around the current value and averaging every $1.1 \mathrm{~s}$. Each spectrum is composed of 1024 points, which gives very high spectral resolution $\left(\sim 4-7 \times 10^{-4} \mathrm{~cm}^{-1}\right)$ depending on the micro-window $(\sim 0.4-$ $0.7 \mathrm{~cm}^{-1}$ ) swept by the laser. The laser beam was directed through the multipass cell where it was selectively absorbed by the HCHO spectral features. The output beam was directed onto a liquid- $\mathrm{N}_{2}$ cooled $\mathrm{HgCdTe}$ detector.

\section{Results and discussion}

Formaldehyde has been generated in the chamber under two types of experimental conditions, corresponding to two different concentration levels of $\mathrm{C}_{2} \mathrm{H}_{4}$ and $\mathrm{O}_{3}$ : one at higher concentration in order to calibrate the TDLAS instrument using FTIR spectroscopy measurement, and another one at lower concentration to intercompare TDLAS and FTIR performances. This formaldehyde production mean has been earlier used by different groups 
for the calibration of instruments working at atmospheric concentration levels of formaldehyde (e.g. Brauers et al., 2007). Both sets of experiments were conducted without adding $\mathrm{OH}$ radicals scavenger to the reactants mixture (that could be generated during the ozonolysis of ethene), which implies that formaldehyde could also be produced through the reaction of $\mathrm{OH}$ with ethene (Paulson et al., 1999; Rickard et al., 1999; Mihelcic et al., 1999; Fenske et al., 2000; Kroll et al., 2001).

\subsection{Rate constant of the reaction of ozone with ethene}

Prior to TDLAS calibration, a check of the chemical system used to generate formaldehyde was performed by deriving the rate constant value for the ethene ozonolysis reaction under pseudo-first order conditions. The measurements were conducted at $760 \pm 1$ Torr and $294 \pm 1 \mathrm{~K}$. One typical initial set of $\mathrm{C}_{2} \mathrm{H}_{4}$ and $\mathrm{O}_{3}$ volume mixing ratios was $4.5 \pm 0.3$ ppm and $465.0 \pm 0.1 \mathrm{ppb}$, respectively. Figure 1 shows the plot of ozone consumption versus reaction time in the absence and presence of $\mathrm{C}_{2} \mathrm{H}_{4}$ for these initial conditions. The reaction rate constant derived from this run is $\mathrm{k}=(1.55 \pm 0.11) \times 10^{-18} \mathrm{~cm}^{3}$ molecule ${ }^{-1} \mathrm{~s}^{-1}$, which is in excellent agreement with the recommended value $\mathrm{k}=(1.6 \pm 0.2) \times 10^{-18} \mathrm{~cm}^{3}$ molecule $\mathrm{s}^{-1}$ (Atkinson et al., 2006), indicating that the consumption of $\mathrm{O}_{3}$ in our experimental system was not affected by any noticeable side reactions.

\subsection{Validation of the formaldehyde FTIR spectrum recorded in the Euphore atmospheric simulation chamber}

The reaction of ozone with ethene is known to produce formaldehyde with a yield near unity (Horie and Moortgat, 1998; Neeb et al., 1998; Brauers et al., 2007; Wegener et al., 2007). In addition, $\mathrm{OH}$ radicals are also produced, with a yield of $\sim 0.16$ (Atkinson et al., 2006). The $\mathrm{OH}$ radicals formed could react with both ethene and formaldehyde. However, considering the concentrations of $\mathrm{O}_{3}$ and ethene used in this first experiment and the roomtemperature reaction rate constant of $\mathrm{OH}$ with $\mathrm{HCHO}\left(\mathrm{k}=8.5 \times 10^{-12} \mathrm{~cm}^{3}\right.$ molecule $\left.{ }^{-1} \mathrm{~s}^{-1}\right)$ and with $\mathrm{C}_{2} \mathrm{H}_{4}\left(\mathrm{k}=7.9 \times 10^{-12} \mathrm{~cm}^{3}\right.$ molecule $\left.\mathrm{s}^{-1}\right)$ (Atkinson et al., 2006), it can be concluded that the $\mathrm{OH}$ radicals react essentially with ethene. Hence, the observed $\mathrm{HCHO}$ resulted from the reactions of ethene with both $\mathrm{OH}$ and $\mathrm{O}_{3}$.

During the experiments, $\mathrm{HCHO}$ concentrations were derived using a scaled reference spectrum recorded between 4000 and $400 \mathrm{~cm}^{-1}$ at the Euphore facilities (EUPHORE FTIR 
References Database). This spectrum, displayed in Fig. 2, has been recorded for a HCHO mixing ratio of $892.4 \mathrm{ppb}$ at $\mathrm{T}=296.5 \mathrm{~K}$ and $\mathrm{P}=1004.5 \mathrm{mbar}$, i.e. $2.21 \times 10^{13}$ molecule $\mathrm{cm}^{-3}$, obtained with $553.4 \mathrm{~m}$ path length and a resolution of $1 \mathrm{~cm}^{-1} .1 \sigma$-precision has been attributed to the FTIR HCHO measurement, resulting in $6 \%$ uncertainty on the measured concentration.

The calibration of the Euphore IR spectrum has been obtained with only one injection of paraformaldehyde. Therefore, Integrated Band Intensities (IBIs) have been calculated in order to ensure the reliability of this spectrum. The IBIs have been defined in the ranges 1660-1820 and 2600-3100 $\mathrm{cm}^{-1}$ and compared to the existing literature data. In a given spectral region, an IBI is determined using Beer-Lambert law, as follows:

$\mathrm{A}=\sigma \times \mathrm{L} \times \mathrm{c}$

where A is the IR absorbance (base e) for a given wavenumber $\tilde{v}, \sigma$ is the absorption cross section (in $\mathrm{cm}^{2}$ molecule ${ }^{-1}$ ), $\mathrm{L}$ is the absorption path length (in $\mathrm{m}$ ) and $\mathrm{C}$ is the $\mathrm{HCHO}$ concentration (in molecule $\mathrm{cm}^{-3}$ ). By integration on the spectral region,

$\int A \times d \tilde{v}=\int \sigma \times L \times C \times d \tilde{v}$

The IBI can be deduced as

$I B I=\int \sigma \times d \tilde{v}$

The values obtained using the Euphore spectrum are in excellent agreement with those reported in the literature, as shown in Table 1. The Euphore values, $(1.265 \pm 0.063) \times 10^{-17} \mathrm{~cm}$ molecule $^{-1}$ at $1660-1820 \mathrm{~cm}^{-1}$ and $(2.830 \pm 0.141) \times 10^{-17} \mathrm{~cm} \mathrm{molecule}^{-1}$ at $2600-3100 \mathrm{~cm}^{-1}$, match within $1 \%$ the average of the previous values, $(1.263 \pm 0.030) \times 10^{-17} \mathrm{~cm} \mathrm{molecule}^{-1}$ and $(2.805 \pm 0.087) \times 10^{-17} \mathrm{~cm}$ molecule ${ }^{-1}$, respectively. Moreover, the ratio 2.24 between the 2600-3100 and 1660-1820 $\mathrm{cm}^{-1}$ Euphore IBIs is in excellent agreement with the previous determined ratios 2.21-2.25 (Perrin et al., 2009). Therefore, we used this Euphore IR spectrum to derive the absolute concentrations of formaldehyde $[\mathrm{HCHO}]_{\text {ICARE }}$ (in molecule $\mathrm{cm}^{-3}$ ) obtained at the ICARE chamber using the formula:

$[\mathrm{HCHO}]_{\mathrm{ICARE}}=[\mathrm{HCHO}]_{\text {Euphore }} \times \frac{L_{\text {Euphore }}}{L_{\mathrm{ICARE}}} \times \frac{T_{\text {ICARE }}}{T_{\text {Euphore }}} \times \frac{P_{\text {Euphore }}}{P_{\mathrm{ICARE}}}$

where $[\mathrm{HCHO}]_{\text {Euphore }}$ is the $\mathrm{HCHO}$ concentration of the calibrated spectra (in molecule $\mathrm{cm}^{-3}$ ), $L$ the optical path lengths (in $\mathrm{m}$ ), $T$ the temperatures (in $\mathrm{K}$ ) and $P$ the pressures (in Torr) of the considered chambers. These results led to consistency between the concentrations of HCHO 
derived from the bands centred at $1746 \mathrm{~cm}^{-1}$ (i.e., the $1660-1820 \mathrm{~cm}^{-1}$ region) and at $2800 \mathrm{~cm}^{-}$ ${ }^{1}$ (i.e., the $2600-3100 \mathrm{~cm}^{-1}$ region), which are found equal within uncertainties (1\%) and very well correlated $\left(\mathrm{R}^{2}=0.9937\right)$, as shown in Fig. 3 .

\subsection{Formaldehyde formation yield deduced from FTIR spectrometry}

Both FTIR bands have been used to quantify the formation yield of formaldehyde from the runs conducted in the first experimental conditions (e.g., with initial volume mixing ratios: $\left[\mathrm{C}_{2} \mathrm{H}_{4}\right]_{0}=4.5 \mathrm{ppm}$ and $\left[\mathrm{O}_{3}\right]_{0}=465 \mathrm{ppb}$ ). Figure 4 shows a linear regression of the plot of $\mathrm{HCHO}$ concentration with respect to ozone consumption at the first stage of the reaction, which leads to a formation yield of $\left(0.96 \pm 0.04 ; r^{2}=0.9884\right)$ and $\left(0.90 \pm 0.03 ; r^{2}=0.9961\right)$ using the 1746 and $2800 \mathrm{~cm}^{-1}$ centred bands, respectively, and so, to a mean value of $0.93 \pm 0.05$. This result is in good agreement with the previous published data, i.e. $0.77-1.00$ (Horie and Moortgat, 1998; Neeb et al., 1998; Brauers et al., 2007; Wegener et al., 2007) and thus gives great confidence in the reliability of the $\mathrm{HCHO}$ concentration measured by the FTIR apparatus. Moreover, the absence of formaldehyde polymerization due to the in situ generation of $\mathrm{HCHO}$ at very low partial pressure $(<0.001 \mathrm{hPa})$ is validated, in agreement with Gratien et al. (2007).

\subsection{Calibration of the ro-vibrational line intensities measured by TDLAS by FTIR spectrometry}

The absorption cross section at a given wavenumber $\tilde{v}_{0}$ can be expressed as:

$$
\sigma\left(\tilde{v}_{0}\right)=S\left(\tilde{v}_{0}\right) \cdot g\left(\tilde{v}-\tilde{v}_{0}\right)
$$

where $S\left(\tilde{v}_{0}\right)$ is the ro-vibrational line intensity (in $\mathrm{cm}$ molecule $\left.{ }^{-1}\right)$ and $g\left(\tilde{v}-\tilde{v}_{0}\right)$ is the normalized absorption profile (in $\mathrm{cm}$ ). The calibration of the line intensities is based on the Beer-Lambert law:

$$
S\left(\tilde{v}_{0}\right)=\frac{A}{C \cdot g\left(\tilde{v}-\tilde{v}_{0}\right) \cdot L}
$$

where $C$ is the $\mathrm{HCHO}$ concentration (in molecule $\mathrm{cm}^{-3}$ ), $A$ is the absorbance (in base e) and $\mathrm{L}$ is the path length (in $\mathrm{cm}$ ). The principle of the retrieval is to fit the experimental absorbance $A$ to the synthetic one, $S\left(\tilde{v}_{0}\right) . C . g\left(\tilde{v}-\tilde{v}_{0}\right) . L$, by adjusting the line intensity $S\left(\tilde{v}_{0}\right)$. A linear leastsquare algorithm (of Levenberg-Marquardt) was used for minimizing the difference between these experimental and synthetic absorbances. The $\mathrm{HCHO}$ concentration $C$ is known from the 
FTIR simultaneous measurements. This calibration was performed at high $\mathrm{HCHO}$ concentrations, corresponding to volume mixing ratios above $250 \mathrm{ppb}$, to maximise the signal-to-noise ratio and therefore the precision. The profile $g\left(\tilde{v}-\tilde{v}_{0}\right)$ is the convolution of the HCHO molecular Voigt profile, including the air-collisional broadening and the Doppler broadening half-widths, with the laser linewidth determined at lower pressure $(\sim 6 \mathrm{hPa})$ where its magnitude is not negligible compared to the air-collisional broadening. The air-broadening half-widths and the line positions (the central wavenumber $\tilde{v}_{0}$ ) were taken from Perrin et al. study (2009), in order to realize direct comparisons with this study and because there was no means to measure these parameters in our present experiments. Moreover, since our experiments were all performed at constant temperature, $294 \pm 1 \mathrm{~K}$, the temperature dependencies of the air-broadening coefficients and of the line intensities were not taken into account. Figure 5 shows an example of experimental and simulated transmission $(T)$ spectra from which the absorbance $(A=-\ln T)$ can be deduced, and the associated residual, i.e. the difference between the experimental and the synthetic spectra.

All the results are gathered in Table 2 and compared to the previous studies. Given our experimental pressure conditions (leading to line broadening) and the TDLAS resolution, rovibrational lines positioned closer than $10^{-2} \mathrm{~cm}^{-1}$ are undistinguished in our experiments. Therefore, the comparison is made with the sum of the individual line intensities of the other studies within this limit. The overall uncertainties have been evaluated. The main systematic error originates from the laser linewidth determination $(9 \%)$. The precision includes the experimental scatter $(1.3 \%$ at $1 \sigma$ level for seven determinations) and the precision on the fit $(2 \%, 1 \sigma)$. Using the error propagation method (i.e. the square root of the quadratic sum of all errors) leads to an estimated overall uncertainty of about $10 \%$. The agreement is good with the calculated values Perrin et al. (2009) for the lines at $2909.71 \mathrm{~cm}^{-1}$ (within 13\%) and $2914.46 \mathrm{~cm}^{-1}$ (within 9\%), and very good (within 4\%) for the $2912.09 \mathrm{~cm}^{-1}$ line, taking into account the $7 \%$ uncertainty of the later. The agreement is also very good at $2914.46 \mathrm{~cm}^{-1}$ (within 3.4\%) if the experimental value obtained in this study is taken $\left(5.91 \pm 0.3 \times 10^{-20} \mathrm{~cm}\right.$ molecule $^{-1}$; Jacquemart, 2009). In contrast, this is clearly not the case for the previous HITRAN 2004 database (Rothman et al., 2005), with over evaluations ranging from about 50 to $150 \%$. We then confirm the validity of the line intensities calculated by Perrin et al. (2009) included in the new HITRAN database (Rothman et al., 2009). Thus, the use of FTIR bands, consistent each other between both spectral domains (1660-1820 and 2600-3100 $\mathrm{cm}^{-1}$ ) and in 
agreement with the study by Perrin et al. (2009), leads to sensible and reliable results for the particular lines studied here. The interest of using one of these lines for in situ stratospheric measurements is developed in Section 3.6, compared with the other lines in the $3.6 \mu \mathrm{m}(2600-$ $3100 \mathrm{~cm}^{-1}$ ) spectral region.

\subsection{Performances of the TDLAS instrument}

The other goal of the study was to assess the performances of the TDLAS instrument, with a view of completing the atmospheric simulation chamber instrumentation. A second set of experiments of ethene ozonolysis at $760 \pm 1$ Torr and $294 \pm 1 \mathrm{~K}$ has been performed to this end, with initial much lower $\mathrm{O}_{3}$ and $\mathrm{C}_{2} \mathrm{H}_{4}$ volume mixing ratios (e.g., 219.0 $\pm 0.1 \mathrm{ppb}$ and $681 \pm 30 \mathrm{ppb}$, respectively) giving rise to lower production levels of formaldehyde $(<25 \mathrm{ppb}$ in $1.5 \mathrm{~h}$ reaction time). Only the $2800 \mathrm{~cm}^{-1}$ centred band was used for $\mathrm{HCHO}$ quantification by FTIR due to a better sensitivity than the $1746 \mathrm{~cm}^{-1}$ centred band. Using one of the TDLAS lines studied reported in the above section, we could simultaneously follow the HCHO formation with a high frequency (each $1.1 \mathrm{~s}$; see section 2.2), as illustrated in Fig. 6 for the above quoted initial mixing ratios. Of course, due to the calibration of the TDLAS by the FTIR spectrometer, the results of both techniques are in agreement. However, what is particularly noticeable is the greater data number with less experimental scatter for TDLAS than for FTIR, as shown with $1 \sigma$ error bars labelled on each measurement point for both setups in Fig. 6. The $1 \sigma$ precision for TDLAS with $4 \mathrm{~s}$ averaging (the time for cell replenishment by the gases) for $112.3 \mathrm{~m}$ path length is $170 \mathrm{ppt} \mathrm{HCHO}$ at $40 \mathrm{hPa}$ (30 Torr), whereas the $1 \sigma$ precision for FTIR is $\sim 2.4 \mathrm{ppb}$ (166 m path length) in $255 \mathrm{~s}$ response time. This TDLAS precision leads to a $2 \sigma$ detection limit of $88 \mathrm{ppt}$ in $60 \mathrm{~s}$ acquisition time (the sensitivity of the technique increased as the square root of the collection time). So, the TDLAS short response time allows for lowering the detection limit of the reaction products, e.g. HCHO in the present study, and thus improves the accuracy of reaction mechanism studies (e.g., the branching ratios of multichannel reactions). These performances are similar as those from another TDLAS (Fried et al., 2008), as shown in Table 3, and should even be improved to a detection limit of $35 \mathrm{ppt}$ in $60 \mathrm{~s}$ if the path length would be increased to $280 \mathrm{~m}$, which seems possible with mirrors of better quality (reflectivity $>99 \%$ ) than the current ones. In contrast, Fried et al. (2008) used a multipass absorption cell that does not allow for reaching a so long optical path, and the sensitivity and accuracy of their HCHO measurements 
are primarily due to the removing of $\mathrm{H}_{2} \mathrm{O}$ (which generates spectroscopic interferences) and to the calibration of $\mathrm{HCHO}$ concentration, obtained by recording cyclically the background signal (without $\mathrm{HCHO}$ ) and a signal from a HCHO standard. In Table 3 are summarized the performances of the different current on-line measurement techniques, only from the detection limit and response time points of view. A more extensive comparison is out of the scope of the present paper. This has been already done recently by Hak et al. (2005), Wisthaler et al. (2008) and Hottle et al. (2009), also including off-line techniques. Here we have considered the most recently developed techniques, so with on-line measurements, namely FTIR, Differential Optical Absorption Spectroscopy (DOAS), Laser Induced Fluorescence (LIF), fluorimetric Hantzsch reaction, and Proton-Transfer Reaction Mass Spectrometry. It is seen that the TDLAS technique offers the best compromise between sensitivity and time resolution, being only in real competition with LIF.

\subsection{Selection of spectral lines in the $2600-3100 \mathrm{~cm}^{-1}$ band for HCHO stratospheric TDLAS measurements}

The three TDLAS lines $\left(2909.71,2912.09\right.$ and $2914.46 \mathrm{~cm}^{-1}$ ) studied in the present work may be used for in situ stratospheric measurements. These are among the most intense R-branch lines of the HCHO $v_{5}$ band, compared to other lines in the $3.6 \mu \mathrm{m}\left(2600-3100 \mathrm{~cm}^{-1}\right)$ spectral region. The feasibility of the measurements depends on the spectral interferences by other atmospheric species and on the detection limit of the instrument. Applied to the stratosphere, the detection limit derived in the laboratory measurements (in the above Section), that is $35 \mathrm{ppt} \mathrm{HCHO}$ for $280 \mathrm{~m}$ path length at $40 \mathrm{hPa}$ and $294 \mathrm{~K}$, reduces for instance to $6 \mathrm{ppt}$ at about $16 \mathrm{~km}$ altitude and to $27 \mathrm{ppt}$ at $\sim 25 \mathrm{~km}$, corresponding to typical pressures and temperatures of $110 \mathrm{hPa}$ and $200 \mathrm{~K}$ and $25 \mathrm{hPa}$ and $220 \mathrm{~K}$, respectively, for the $431 \mathrm{~m}$ path length of SPIRALE balloon-borne instrument. These limits are well below the typical $\mathrm{HCHO}$ volume mixing ratios of $20 \mathrm{ppt}$ and $50 \mathrm{ppt}$ existing at the corresponding altitudes.

The selection of a suitable absorption line is critical for a species such as formaldehyde, which is a relatively weak absorber in the mid-infrared region and not very abundant in the stratosphere. In order to facilitate the $\mathrm{HCHO}$ retrievals from high-resolution measurements, it is necessary to select a strong and well-isolated absorption line to minimize as much as possible the impact of interfering species absorbing in the same spectral region. For this purpose, a simulation approach has been adopted to represent simultaneously the absorption 
lines corresponding to most of stratospheric molecular species. Hence, a home-made program has been developed and was used to simulate interactively the transmission spectra of all the species included in the HITRAN 2008 database (Rothman et al., 2009) under a standard atmospheric condition defined by mid-latitude $\left(45^{\circ}\right)$ and time of the day (McClatchey et al., 1972; ESSA, NASA and U.S. Air Force, 1976). The operator has flexibility to change these parameters and other ones, such as the selected molecular species considered at a given altitude, the optical path length, and the spectral micro-window width. Line-by-line simulations have been performed over the whole $2600-3100 \mathrm{~cm}^{-1}$ domain, under a typical stratospheric condition, i.e. for $50 \mathrm{ppt} \mathrm{HCHO}$ at $25 \mathrm{~km}$ altitude. Figure 7 presents detailed parts of this band, with focus on the absorption lines of formaldehyde studied in this work. At $2909.71 \mathrm{~cm}^{-1}$ and $2914.46 \mathrm{~cm}^{-1}$ (Fig. 7, top and bottom), the HCHO lines are strongly hindered by those of $\mathrm{O}_{3}$ and $\mathrm{CH}_{4}$, respectively. It is clear that these lines cannot be used for the quantitative detection of this molecule in the stratosphere. At $2912.09 \mathrm{~cm}^{-1}$ (Fig. 7, middle), the formaldehyde line is partly perturbed by that of OCS located at $2912.106 \mathrm{~cm}^{-1}$, but can be used taking into account this OCS line during the retrieval process.

Among all the HCHO lines in the $2600-3100 \mathrm{~cm}^{-1}$ region, we found that those located at 2809.83 and $2831.64 \mathrm{~cm}^{-1}$ are the most suited for the detection of this molecule, as illustrated in Fig. 8 (a) and (c), respectively. The latter has been used for long time by Fried et al. (2008, and references therein). These lines present the advantage to be relatively strong and are sufficiently isolated from those of other trace gases. Between the previous HITRAN database (Rothman et al., 2005) and the new one (Rothman et al., 2009, based on Perrin et al., 2009), the $2831.64-\mathrm{cm}^{-1}$ line intensity value has been slightly corrected by an increase whereas the $2912.09-\mathrm{cm}^{-1}$ line intensity has been decreased by a factor of $\sim 2.5$, which leads to about the same value for both lines $\left(\sim 6.0 \pm 0.2 \times 10^{-20} \mathrm{~cm} \mathrm{molecule}^{-1}\right)$, and therefore decrease the interest of using the later one studied for atmospheric measurements. Finally, it is to be noted that the HCHO absorption lines located at $2814.48 \mathrm{~cm}^{-1}$ and $2856.17 \mathrm{~cm}^{-1}$ are also clear of interfering species but about $20-30 \%$ lower than the most interesting ones quoted above, as shown in Fig. 8.

\section{Conclusions}

This study presents a validation of a tunable diode laser absorption spectrometer (TDLAS) for formaldehyde measurement by a FTIR spectrometer in an atmospheric 
simulation chamber. As a first step, the FTIR HCHO spectrum, recorded in Euphore chamber and used as a reference in the present work, has been compared to most of other ones published. The both absorption integrated band intensities (1660-1820 and 2600-3100 $\mathrm{cm}^{-1}$ ) have been revealed to be in agreement within $1 \%$ with the average of these previous ones, including the most recent study of Perrin et al. (2009), and also consistent each other as in the latter. Formaldehyde was generated in situ from the reaction of ethene with ozone. This welldocumented reaction has been then investigated by FTIR and ozone UV-monitor, leading to a rate constant and a formaldehyde formation yield at $294 \mathrm{~K}$ that are in excellent agreement with the compiled literature data. The three ro-vibrational line intensities (at 2909.71, 2912.09 and $2914.46 \mathrm{~cm}^{-1}$ ) used in the very high resolution TDLAS method were calibrated by FTIR spectra simultaneously recorded during ethene ozonolysis. The inferred values (Table 2) confirm those from the updated HITRAN database (Rothman et al., 2009), based on the study of Perrin et al. (2009) within 4-13\%.

In addition, the TDLAS performances at low concentration of formaldehyde were assessed. A $2 \sigma$ detection limit of $88 \mathrm{ppt}$ volume mixing ratio with a response time of $60 \mathrm{~s}$ (or 340 ppt in $4 \mathrm{~s}$ ) was obtained at 30 Torr and $294 \mathrm{~K}$, for $112 \mathrm{~m}$ optical path, potentially leading to $35 \mathrm{ppt}$ for $280 \mathrm{~m}$. In comparison with the widespread conventional methods used in atmospheric simulation chamber studies, our TDLAS has been shown to be more sensitive than the on-line techniques (FTIR, DOAS, Hantzsch method, PTR-MS), and as much as sensitive as the dinitrophenylhydrazine (DNPH) derivatization followed by off-line high pressure liquid chromatography ultraviolet (HPLC-UV) analysis, but this one needing more than one hour sampling (Whistaler et al., 2008). Therefore, the TDLAS technical performances in terms of response time and detection limit are of great added value for laboratory applications, including mechanism and kinetics of chemical reactions. However, one should keep in mind that the number of species to be monitored and the accuracy of the monitoring are limited by the advances in the very high-resolution spectroscopic databases. The TDLAS implementation can thus be seen as a complementary analysis tool of chamber studies.

Concerning atmospheric embarked in situ measurements, formaldehyde quantification appears to be feasible in the stratosphere with TDLAS instrumentation such as SPIRALE balloon-borne spectrometer, using the $2912.09 \mathrm{~cm}^{-1}$ line with detection limits above few tens of ppt for $431 \mathrm{~m}$ optical path length. In the upper troposphere, the $2831.64 \mathrm{~cm}^{-1}$ line is a better choice since the OCS species is abundant and would hinder the $2912.09 \mathrm{~cm}^{-1}$ line. Another 
interesting line, of similar intensity $\left(>5 \times 10^{-20} \mathrm{~cm} \mathrm{molecule}{ }^{-1}\right)$ and clear of known spectroscopic interferences, is at $2809.83 \mathrm{~cm}^{-1}$. Moreover, the $1660-1820 \mathrm{~cm}^{-1}$ band has to be considered as an alternative, with line intensities of the same order of magnitude. The use of the $1764.9 \mathrm{~cm}^{-1}$ line as in the work of Herndon et al. (2007) is an example for stratospheric measurements, but less convenient in the upper troposphere where $\mathrm{H}_{2} \mathrm{O}$ lines interfere.

\section{Acknowledgements}

The authors thank the SPIRALE technical team (M. Chartier, L. Pomathiod, G. Chalumeau) for successful TDLAS operations in the ICARE atmospheric simulation chamber, and A. Perrin (LISA, CNRS-Université Paris 12) and D. Jacquemart (LADIR, CNRS-Université Paris 6) for fruitful discussions and making available the line intensity value measured at $2914.46 \mathrm{~cm}^{-1}$. This work was financially supported by the European Commission through the $7^{\text {th }}$ Framework Programme under the grant agreement \#228335 (EUROCHAMP-2 Project) and by the French CNRS-INSU Programme National de Chimie Atmosphérique.

\section{References}

Anderson L G, Lanning J A, Barrell R, Miyagishima J, Jones R H, Wolfe P, 1996. Sources and sinks of formaldehyde and acetaldehyde: an analysis of Denver's ambient concentration data. Atmospheric Environment, 30: 2113-123.

Atkinson R, Baulch D L, Cox R A, Crowley J N, Hampson R F, Hynes R G, Jenkin M E, Rossi M J, Troe J, 2006. Evaluated kinetic and photochemical data for atmospheric chemistry: Volume II - gas phase reactions of organic species. Atmospheric Chemistry and Physics, 6 : $3625-4055$.

Barth M C, Kim S W, Skamarock W C, Stuart A L, Pickering K E, Ott L E, 2007. Simulations of the redistribution of formaldehyde, formic acid, and peroxides in the 10 July 1996 Stratospheric-Tropospheric Experiment: Radiation, Aerosols, and Ozone deep convection storm, Journal of Geophysical Research, 112: D13310. DOI: 10.1029/2006JD008046. 
Berthet G, Huret N, Lefèvre F, Moreau G, Robert C, Chartier M, Catoire V, Barret B, Pisso I, Pomathiod L, 2006. On the ability of chemical transport models to simulate the vertical structure of the $\mathrm{N}_{2} \mathrm{O}, \mathrm{NO}_{2}$ and $\mathrm{HNO}_{3}$ species in the mid-latitude stratosphere. Atmospheric Chemistry and Physics, 6: 1599-1609.

Berthet G, Renard J B, Catoire V, Chartier M, Robert C, Huret N, Coquelet F, Bourgeois Q, Rivière E D, Barret B, Lefèvre F, Hauchecorne A, 2007. Remote sensing measurements in the polar vortex: comparison to in situ observations and implications for the simultaneous retrievals and analysis of the $\mathrm{NO}_{2}$ and OClO species. Journal of Geophysical Research, 112: D21310, doi:10.1029/2007JD008699.

Brauers T, Bossmeyer J, Dorn H P, Schlosser E, Tillmann R, Wegener R, Wahner A, 2007. Investigation of the formaldehyde differential absorption cross section at high and low spectral resolution in the simulation chamber SAPHIR. Atmospheric Chemistry and Physics, 7: $3579-3586$.

Carlier P, Hannachi H, Mouvier G, 1986. The chemistry of carbonyl compounds in the atmosphere - a review. Atmospheric Environment, 20: 2079-2099.

Coheur P F, Herbin H, Clerbaux C, Hurtmans D, Wespes C, Carleer M, Turquety S, Rinsland C P, Remedios J, Hauglustaine D, Boone C D, Bernath P F, 2007. ACE-FTS observation of a young biomass burning plume: first reported measurements of $\mathrm{C}_{2} \mathrm{H}_{4}, \mathrm{C}_{3} \mathrm{H}_{6} \mathrm{O}, \mathrm{H}_{2} \mathrm{CO}$ and PAN by infrared occultation from space. Atmospheric Chemistry and Physics, 7: 5437-5446.

Cortesi U, Lambert J C, De Clercq C, Bianchini G, Blumenstock T, Bracher A, Castelli E, Catoire V, Chance K V, De Mazière M, Demoulin P, Godin-Beekmann S, Jones N, Jucks K. Keim C, Kerzenmacher T, Kuellmann H, Kuttippurath J, Iarlori M, Liu G Y, Liu Y, McDermid I S, Meijer Y J, Mencaraglia F, Mikuteit S, Oelhaf H, Piccolo C, Pirre M, et al., 2007. Geophysical validation of MIPAS-ENVISAT operational ozone data. Atmospheric Chemistry and Physics, 7: 4807-4867.

Crawford J, Davis D, Olson J, Chen G, Liu S, Gregory G, Barrick J, Sachse G, Sandholm S, Heikes B, Singh H, Blake D, 1999. Assessment of upper tropospheric $\mathrm{HO}_{\mathrm{x}}$ sources over the tropical Pacific based on NASA GTE/PEM data: Net effect on $\mathrm{HO}_{\mathrm{x}}$ and other photochemical parameters, Journal of Geophysical Research, 104(D13): 16255. DOI: 10.1029/1999JD900106. 
Dufour G, Szopa S, Barkley M P, Boone C D, Perrin A, Palmer P I, Bernath P F, 2009. Global upper-tropospheric formaldehyde: seasonal cycles observed by the ACE-FTS satellite instrument. Atmospheric Chemistry and Physics, 9: 3893-3910.

ESSA, NASA, U.S. Air Force, 1976. U.S. Standard Atmosphere 1976 and Supplements 1966. U.S. Government Printing Office, Washington D C, U.S.A.

EUPHORE FTIR References Database, (available online at http://euphore.es/FTIRReferences/index.htm).

Fenske J D, Hasson A S, Paulsen S E, Kuwata K T, Ho A, Houk K N, 2000. The pressure dependence of the $\mathrm{OH}$ radical yield from ozone-alkene reactions. Journal of Physical Chemistry A, 104: 7821-7833.

Fried A, Walega J G, Olson J R, Crawford J H, Chen G, Weibring P, Richter D, Roller C, Tittel F K, Heikes B G, Snow J A, Shen H, O’Sullivan D W, Porter M, Fuelberg H, Halland J, Millet D B, 2008. Formaldehyde over North America and the North Atlantic during the summer 2004 INTEX campaign: Methods, observed distributions, and measurement-model comparisons. Journal of Geophysical Research, 113: D10302, doi:10.1029/2007JD009185.

Gratien A, Picquet-Varrault B, Orphal J, Perraudin E, Doussin J F, Flaud J M, 2007. Laboratory intercomparison of the formaldehyde absorption cross sections in the infrared $\left(1600-1820 \mathrm{~cm}^{-1}\right)$ and ultraviolet $(300-360 \mathrm{~nm})$ spectral regions. Journal of Geophysical Research, 112: D05305, doi:10.1029/2006JD007201.

Hak C, Pundt I, Trick S, Kern C, Platt U, Dommen J, Ordóñez C, Prévôt A S H, Junkermann W, Astorga-Lloréns C B, Larsen R, Mellqvist J, Strandberg A, Yu Y, Galle B, Kleffmann J, Lörzer J C, Braathen G O, Volkamer R, 2005. Intercomparison of four different in-situ techniques for ambient formaldehyde measurements in urban air. Atmospheric Chemistry and Physics, 5: 2881-2900.

Heikes B G, 1992. Formaldehyde and hydroperoxides at Mauna Loa Observatory. Journal of Geophysical Research, 97(D16): 18001-18013.

Herndon S C, Nelson Jr D D, Yongquan L, Zahniser M S, 2005. Determination of line strengths for selected transitions in the $v_{3}$ relative to the $v_{1}$, and $v_{5}$ bands of $\mathrm{H}_{2} \mathrm{CO}$. Journal of Quantitative Spectroscopy \& Radiative Transfer, 90: 207-216. 
Herndon S C, Zahniser M S, Nelson Jr D D, Shorter J, McManus J B, Jiménez R., Warneke C., de Gouw J A, 2007. Airborne measurements of $\mathrm{HCHO}$ and $\mathrm{HCOOH}$ during the New England Air Quality Study 2004 using a pulsed quantum cascade laser spectrometer. Journal of Geophysical Research, 112: D10S03, doi:10.1029/2006JD007600.

Horie O, Moortgat G K, 1998. The effect of the addition of CO on the reaction of ozone with ethane. Chemical Physics Letters, 288: 464-472.

Hottle J R, Huisman A J, Digangi J P, Kammrath A, Galloway M M, Coens K L, Keutsch F $\mathrm{N}, 2009$. A laser induced fluorescence-based instrument for in situ measurements of atmospheric formaldehyde. Environmental Science and Technology, 43: 790-795.

Huret N, Pirre M, Hauchecorne A, Robert C, Catoire V, 2006. On the vertical structure of the stratosphere at midlatitudes during the first stage of the polar vortex formation and in the polar region in the presence of a large mesospheric descent. Journal of Geophysical Research, 111: D06111, doi:10.1029/2005JD006102.

Jacquemart D, 2009. Personal communication.

Jégou F, Urban J, de La Noë J, Ricaud P, Le Flochmoën E, Murtagh D P, Eriksson P, Jones A, Petelina S, Llewellyn E J, Lloyd N D, Haley C, Lumpe J, Randall C, Bevilacqua R M, Catoire V, Huret N, Berthet G, Renard J B, Strong K, Davies J, Mc Elroy C T, Goutail F, Pommereau J P, 2008. Technical Note: Validation of Odin/SMR limb observations of ozone, comparisons with OSIRIS, POAM III, ground-based and balloon-borne instruments. Atmospheric Chemistry and Physics, 8: 3385-3409.

Jobson B T, McCoskey J K, 2010. Sample drying to improve HCHO measurements by PTRMS instruments: laboratory and field measurements. Atmospheric Chemistry and Physics, 10: $1821-1835$.

Joly L, Robert C, Parvitte B, Catoire V, Durry G, Richard G, Nicoullaud B, Zéninari V, 2008. Development of a spectrometer using a cw DFB quantum cascade laser operating at room temperature for the simultaneous analysis of $\mathrm{N}_{2} \mathrm{O}$ and $\mathrm{CH}_{4}$ in the Earth's atmosphere. Applied Optics, 47: 1206-1214.

Klotz B, Barnes I, Imamura T, 2004. Product study of the gas-phase reactions of $\mathrm{O}_{3}, \mathrm{OH}$ and $\mathrm{NO}_{3}$ radicals with methyl vinyl ether. Physical Chemistry Chemical Physics, 6, 1725-1734. 
Kroll J H, Clarke J S, Donahue N M, Anderson J G, Demerjian K L, 2001. Mechanism of $\mathrm{HO}_{\mathrm{X}}$ formation in the gas-phase ozone-alkene reaction. 1. Direct, pressure-dependent measurements of prompt OH yields. Journal of Physical Chemistry A, 105: 1554-1560.

Lee Y N, Zhou X, Kleinman L I, Nunnermacker L J, Springston S R, Daum P H, Newman L, Keigley W G, Holdren M W, Spicer C W, Young V, Fu B, Parrish D D, Holloway J, Williams J, Roberts J M, Ryerson T B, Fehsenfeld F C, 1998. Atmospheric chemistry and distribution of formaldehyde and several multioxygenated carbonyl compounds during the 1995 Nashville/Middle Tennessee Ozone Study. Journal of Geophysical Research, 103(D17): $22449-22462$.

Lelieveld J, Crutzen P J, 1990. Influences of cloud photochemical processes on tropospheric ozone. Nature, 343: 227-233, doi:10.1038/343227a0.

McClatchey R, Fenn R, Selby J, Volz F, Garing J, 1972. Optical properties of the atmosphere, $3^{\text {rd }}$ ed., AFCRL-TR-72-0497. Environmental Research Paper, 411.

Mébarki Y, Catoire V, Huret N, Berthet G, Robert C, Poulet, G, 2010. More evidence for very short-lived substance contribution to stratospheric chlorine inferred from $\mathrm{HCl}$ balloon-borne in situ measurements in the tropics. Atmospheric Chemistry and Physics, 10: 1-13.

Mihelcic D M, Heitlinger M D, Kley D, Müsgen P, Volz-Thomas A, 1999. Formation of hydroxyl and hydroperoxy radicals in the gas-phase ozonolysis of ethane. Chemical Physics Letters, 301: 559-564.

Moreau G, Robert C, Catoire V, Chartier M, Camy-Peyret C, Huret N, Pirre M, Pomathiod L, Chalumeau G, 2005. SPIRALE: a multispecies in situ balloon-borne instrument with six tunable diode laser spectrometers. Applied Optics, 44(28), 5972-5989.

Müller R, Tilmes S, Grooß J U, Engel A, Oelhalf H, Wetzel G, Huret N, Pirre M, Catoire V, Toon G, Nakajima H, 2007. Impact of mesospheric intrusions on ozone-tracer relations in the stratospheric polar vortex. Journal of Geophysical Research, 112: D23307, doi:10.1029/2006JD008315.

Nakanaga T, Kondo S, Saëki, S, 1982. Infrared band intensities of formaldehyde and formaldehyde-D2. Journal of Chemical Physics, 76: 3860-3865.

Neeb P, Horie O, Moortgat G K, 1998. The ethene-ozone reaction in the gas phase. Journal of Physical Chemistry A, 102: 6778-6785. 
Paulson S E, Fenske J D D, Sen A D, Callahan T W, 1999. A novel small-ratio relative-rate technique for measuring $\mathrm{OH}$ formation yields from the reactions of $\mathrm{O}_{3}$ with alkenes in the gas phase, and its application to the reactions of ethene and propene. Journal of Physical Chemistry A, 103: 2050-2059.

Perrin A, Valentin A, Daumont L, 2006. New analysis of the $v_{1}, v_{5}, 2 v_{4}, v_{4}+v_{6}, 2 v_{6}, v_{3}+v_{4}$, $v_{3}+v_{6}, v_{2}+v_{4}, 2 v_{3}, v_{2}+v_{6}$, and $v_{2}+v_{3}$ bands of formaldehyde $\mathrm{H}_{2} \mathrm{CO}$ : Line positions and intensities in the $3.6 \mu \mathrm{m}$ spectral region. Journal of Molecular Structure, 780: 28-44.

Perrin A, Jacquemart D, KwabiaTchana F, Lacome N, 2009. Absolute line intensities measurements and calculations for the 5.7 and $3.6 \mu \mathrm{m}$ bands of formaldehyde. Journal of Quantitative Spectroscopy \& Radiative Transfer, 110(9-10): 700-716.

Pirre M, Pisso I, Marécal V, Catoire V, Mébarki Y, Robert C, 2008. Intrusion of recent air in midlatitude stratosphere revealed by in situ tracer measurements and trajectory calculations. Journal of Geophysical Research, 113: D11302, doi: 10.1029/2007JD009188.

Possanzini M, Di Palo V, Cecinato A, 2002. Sources and photodecomposition of formaldehyde and acetaldehyde in Rome ambient air. Atmospheric Environment, 36: 31953201 .

Ricaud P, Alexandre D, Barret B, Le Flochmoën E, Motte E, Berthet G, Lefèvre F, Murtagh D, 2007. Measurements of mid-stratospheric formaldehyde from the Odin/SMR instrument. Journal of Quantitative Spectroscopy \& Radiative Transfer, 107: 91-104.

Renard J B, Berthet G, Brogniez C, Catoire V, Fussen D, Goutail F, Oelhaf H, Pommereau J P, Roscoe H K, Wetzel G, Chartier M, Robert C, Balois J Y, Verwaerde C, Auriol F, François P, Gaubicher B, Wursteisen P, 2008. Validation of GOMOS-Envisat vertical profiles of $\mathrm{O}_{3}$, $\mathrm{NO}_{2}, \mathrm{NO}_{3}$, and aerosol extinction using balloon-borne instruments and analysis of the retrievals. Journal of Geophysical Research, 113: A02302, doi:10.1029/2007JA012345.

Rickard A R, Johnson D, McGill C D, Marston G, 1999. OH yields in the gas-phase reactions of ozone with alkenes. Journal of Physical Chemistry A, 103: 7656-7664.

Robert C, 2007. Simple, stable, and compact multiple-reflection optical cell for very long optical paths. Applied Optics, 46(22): 5408-5418.

Rothman L S, Jacquemart D, Barbe A, Chris Bennerc D, Birk M, Brown L R, Carleer M R, Chackerian Jr C, Chance K, Coudert L H, Dana V, Devi V M, Flaud J M, Gamache R R, 
Goldman A, Hartmann J M, Jucks KW, Maki A G, Mandin J Y, Massie S T, Orphal J, Perrin A, Rinsland C P, Smith M A H, Tennyson J, Tolchenov R N, Toth R A, Vander Auwera J, Varanasi P, Wagner G, 2005. The HITRAN 2004 molecular spectroscopic database. Journal of Quantitative Spectroscopy \& Radiative Transfer, 96: 139-204.

Rothman L S, Gordon I E, Barbe A, Chris Bennerc D, Bernath P F, Birk M, Boudon V, Brown L R, Campargue A, Champion J P, Chance K, Coudert L H, Dana V, Devi V M, Fally S, Flaud J M, Gamache R R, Goldman A, Jacquemart D, Kleiner I, Lacome N, Lafferty W J, Mandin J Y, Massie S T, Mikhailenko S N, Miller C E, Moazzen-Ahmadi N, Naumenko O V, Nikitin A V, Orphal J, Perevalov V I, Perrin A, Predoi-Cross A, Rinsland C P, Rotger M, Simeckova M, Smith M A H, Sung K, Tashkun S A, Tennyson J, Toth R A, Vandaele A C, Vander Auwera J, 2009. The HITRAN 2008 molecular spectroscopic database. Journal of Quantitative Spectroscopy \& Radiative Transfer, 110: 533-572.

Seinfeld J H, Pandis S N, 2006. Atmospheric Chemistry and Physics, $2^{\text {nd }}$ Edition, J Wiley \& Sons, Inc, Hoboken, New Jersey (U.S.A.).

Sharpe S W, Johnson T J, Sams R L, Chu P M, Rhoderick G C, Johnson P A, 2004. Gasphase databases for quantitative infrared spectroscopy. Applied Spectroscopy, 58: 1452--1461.

Steck T, Glatthor N, von Clarmann T, Fischer H, Flaud J M, Funke B, Grabowski U, Höpfner M, Kellmann S, Linden A, Perrin A, Stiller G P, 2008. Retrieval of global upper tropospheric and stratospheric formaldehyde $\left(\mathrm{H}_{2} \mathrm{CO}\right)$ distributions from high-resolution MIPAS-Envisat spectra. Atmospheric Chemistry and Physics, 8: 463-470.

Strong K, Wolff M A, Kerzenmacher T E, Walker K A, Bernath P F, Blumenstock T, Boone C, Catoire V et al., 2008. Validation of ACE-FTS $\mathrm{N}_{2} \mathrm{O}$ measurements. Atmospheric Chemistry and Physics, 8: 4759-4786.

Tie X, Brasseur G, Emmons L, Horowitz L, Kinnison D, 2001. Effects of Aerosols on Tropospheric Oxidants: A Global Model Study. Journal of Geophysical Research, 106(D19): $22931-22964$.

Wang D Y, Hopfner M, Blom C E, Ward W E, Fischer H, Blumenstock T, Hase F, Keim C, Liu G Y, Mikuteit S, Oelhaf H, Wetzel G, Cortesi U, Mencaraglia F, Bianchini G, Redaelli G, Pirre M, Catoire V, Huret $\mathrm{N}$ et al., 2007. Validation of MIPAS $\mathrm{HNO}_{3}$ operational data. Atmospheric Chemistry and Physics, 7: 4905-4934. 
Wert B P, Fried A, Henry B, Cartier S, 2002. Evaluation of inlets used for the airborne measurement of formaldehyde. Journal of Geophysical Research, 107(D13): 4163, doi:10.1029/2001JD001072.

Wegener R, Brauers T, Koppmann R, Rodríguez Bares S, Rohrer F, Tillmann R, Wahner A Hansel A, Wisthaler A, 2007. Simulation chamber investigation of the reactions of ozone with short-chained alkenes. Journal of Geophysical Research, 112(D13301): doi:10.1029/2006JD007531.

Wisthaler A E, Apel C, Bossmeyer J, Hansel A, Junkermann W, Koppmann R, Meier R, Müller K, Solomon S J, Steinbrecher R, Tillmann R, Brauers T, 2008. Technical Note: Intercomparison of formaldehyde measurements at the atmosphere simulation chamber SAPHIR. Atmospheric Chemistry and Physics, 8: 2189-2200. 
Table 1. Comparison of the calculated Integrated Band Intensities (IBIs) in the regions 1660$1820 \mathrm{~cm}^{-1}$ and $2600-3100 \mathrm{~cm}^{-1}$ using different IR spectra $(\mathrm{T}=296 \pm 2 \mathrm{~K})$.

\begin{tabular}{|c|c|c|c|c|}
\hline $\begin{array}{c}\text { Wavenumber } \\
\left(\mathrm{cm}^{-1}\right)\end{array}$ & $\begin{array}{c}\text { IBI } \times 10^{17} \\
(\mathrm{~cm} \mathrm{molecule})\end{array}$ & $\begin{array}{c}\text { Resolution } \\
\left(\mathrm{cm}^{-1}\right)\end{array}$ & Method & Reference \\
\hline \multirow{5}{*}{$1660-1820$} & $1.229 \pm 0.040$ & 0.25 & FTIR & Nakanaga et al., 1982 \\
\cline { 2 - 5 } & $1.248 \pm 0.126$ & 1 & FTIR & Klotz et al., 2004 \\
\cline { 2 - 5 } & $1.262 \pm 0.083$ & $\sim 10^{-3}$ & TDLAS & Herndon et al., 2005 \\
\cline { 2 - 5 } & $1.284 \pm 0.064$ & 0.11 & FTIR & Sharpe et al., 2004 \\
\cline { 2 - 5 } & $1.31 \pm 0.04$ & 0.08 & FTIR/UV & Gratien et al., 2007 \\
\cline { 2 - 5 } & $1.242 \pm 0.087$ & 0.0035 & FTIR & Perrin et al., 2009 \\
\cline { 2 - 5 } & $1.265 \pm 0.063$ & 1 & FTIR & Euphore \\
\hline \multirow{5}{*}{$2600-3100$} & $2.708 \pm 0.099$ & 0.25 & FTIR & Nakanaga et al., 1982 \\
\cline { 2 - 5 } & $2.800 \pm 0.140$ & 0.1 & FTIR & Sharpe et al., 2004 \\
\cline { 2 - 5 } & $2.92 \pm 0.10$ & 0.08 & FTIR/UV & Gratien et al., 2007 \\
\cline { 2 - 5 } & $2.79 \pm 0.25$ & 0.0035 & FTIR & Perrin et al., 2009 \\
\cline { 2 - 5 } & $2.830 \pm 0.141$ & 1 & FTIR & Euphore \\
\hline
\end{tabular}


Table 2. Ro-vibrational line intensities determined in this work and comparison with previous studies

\begin{tabular}{|c|c|c|}
\hline Wavenumber $\left(\mathrm{cm}^{-1}\right)$ & Global line intensity $\mathrm{S}^{\mathrm{a}}$ & Reference \\
\hline \multirow[t]{3}{*}{2909.71} & $6.6 \pm 0.7$ & This work \\
\hline & $5.78 \pm 0.41$ & Perrin et al. (2009) ${ }^{b}$ \\
\hline & $10.24^{\mathrm{c}}$ & Rothmann et al. (2005) ${ }^{d}$ \\
\hline \multirow[t]{3}{*}{2912.09} & $6.0 \pm 0.6$ & This work \\
\hline & $6.22 \pm 0.44$ & Perrin et al. $(2009)^{\mathrm{e}}$ \\
\hline & $15.12^{\mathrm{c}}$ & Rothman et al. $(2005)^{\mathrm{f}}$ \\
\hline \multirow[t]{4}{*}{2914.46} & $6.1 \pm 0.6$ & This work \\
\hline & $5.9 \pm 0.3$ & Jacquemart et al. (2009) ${ }^{\mathrm{g}}$ \\
\hline & $5.57 \pm 0.39$ & Perrin et al. (2009) ${ }^{\mathrm{h}}$ \\
\hline & $9.20^{\mathrm{c}}$ & Rothman et al. (2005) ${ }^{\mathrm{i}}$ \\
\hline
\end{tabular}

${ }^{a}$ units of $10^{-20} \mathrm{~cm}$ molecule ${ }^{-1}$; Reported uncertainties are overall, including precision $(1 \sigma)$ and estimated systematic errors. ${ }^{b}$ Sum of two equal intensity lines at 2909.71338 and 2909.71353 $\mathrm{cm}^{-1} .{ }^{\mathrm{c}}$ Unknown uncertainty according to the author. ${ }^{\mathrm{d}}$ Sum of two equal intensity lines at $2909.71300 \mathrm{~cm}^{-1}$. ${ }^{\text {e }}$ Sum of four intensity lines: two of equal intensities (2.84) at 2912.09179 and $2912.09198 \mathrm{~cm}^{-1}$, and two of equal intensities (0.27) at 2912.10063 and $2912.10132 \mathrm{~cm}^{-1}$. ${ }^{\mathrm{f}}$ Sum of three equal intensity lines at $2912.09180 \mathrm{~cm}^{-1}$. ${ }^{\mathrm{g}}$ Experimental value obtained by Jacquemart et al. (2009) in the study of Perrin et al. (2009). ${ }^{\mathrm{h}}$ Sum of two equal intensity (2.771) lines at 2914.45917 and $2914.46110 \mathrm{~cm}^{-1}$ and one intensity line (0.031) at 2914.46962 $\mathrm{cm}^{-1}$. ${ }^{\mathrm{i}}$ Sum of two equal intensity lines at $2914.45980 \mathrm{~cm}^{-1}$. 
Table 3. Comparison of TDLAS with other on-line techniques

\begin{tabular}{|c|c|c|c|}
\hline $\begin{array}{l}\text { Instrumentation } \\
\text { (Reference) }\end{array}$ & $\begin{array}{l}2 \sigma \text { detection limit }^{\mathrm{a}} \\
\text { (optical path length) }\end{array}$ & $\begin{array}{l}\text { Accuracy } \\
(\%)\end{array}$ & $\begin{array}{l}\text { Typical time } \\
\text { resolution }\end{array}$ \\
\hline TDLAS (This work) & $\begin{array}{l}340 \mathrm{ppt}(112.3 \mathrm{~m}) \\
88 \mathrm{ppt}(112.3 \mathrm{~m}) \\
35 \mathrm{ppt}(280 \mathrm{~m})\end{array}$ & 10 & $\begin{array}{l}4 \mathrm{~s} \\
60 \mathrm{~s} \\
60 \mathrm{~s} \\
\end{array}$ \\
\hline TDLAS (Fried et al., 2008) & $\begin{array}{l}360 \mathrm{ppt}(100 \mathrm{~m}) \\
66 \mathrm{ppt}(100 \mathrm{~m})\end{array}$ & 13 & $\begin{array}{l}1 \mathrm{~s} \\
60 \mathrm{~s} \\
\end{array}$ \\
\hline FTIR (This work; Hak et al., 2005) & $\begin{array}{l}400(1000 \mathrm{~m}) \\
4800 \mathrm{ppt}(166 \mathrm{~m})\end{array}$ & $6-27$ & $\begin{array}{l}5 \min \\
4 \min \end{array}$ \\
\hline DOAS $^{b}$ (Wisthaler et al., 2008) & $400 \mathrm{ppt}$ & 6 & $100 \mathrm{~s}$ \\
\hline LIF $^{\mathrm{c}}$ (Hottle et al., 2009) & $\begin{array}{l}34 \mathrm{ppt} \\
6.2 \mathrm{ppt}\end{array}$ & 25 & $\begin{array}{l}1 \mathrm{~s} \\
30 \mathrm{~s}\end{array}$ \\
\hline $\begin{array}{l}\text { Fluorimetric Hantzsch reaction } \\
\text { (Wisthaler et al., 2008) }\end{array}$ & $50-80 \mathrm{ppt}$ & $5-8$ & $1-2 \min$ \\
\hline $\begin{array}{l}\text { PTR-MS }{ }^{\mathrm{d}} \text { (Wisthaler et al., 2008; } \\
\text { Jobson et al., 2010) }\end{array}$ & $80-200 \mathrm{ppt}$ & $10-15$ & $75 \mathrm{~s}$ \\
\hline
\end{tabular}

${ }^{a}$ The $1 \sigma$ precision can be derived as the half of this detection limit. ${ }^{b}$ Differential Optical Absorption Spectroscopy. ${ }^{\mathrm{c}}$ Laser Induced Fluorescence. ${ }^{\mathrm{d}}$ Proton-Transfer Reaction Mass Spectrometry. 


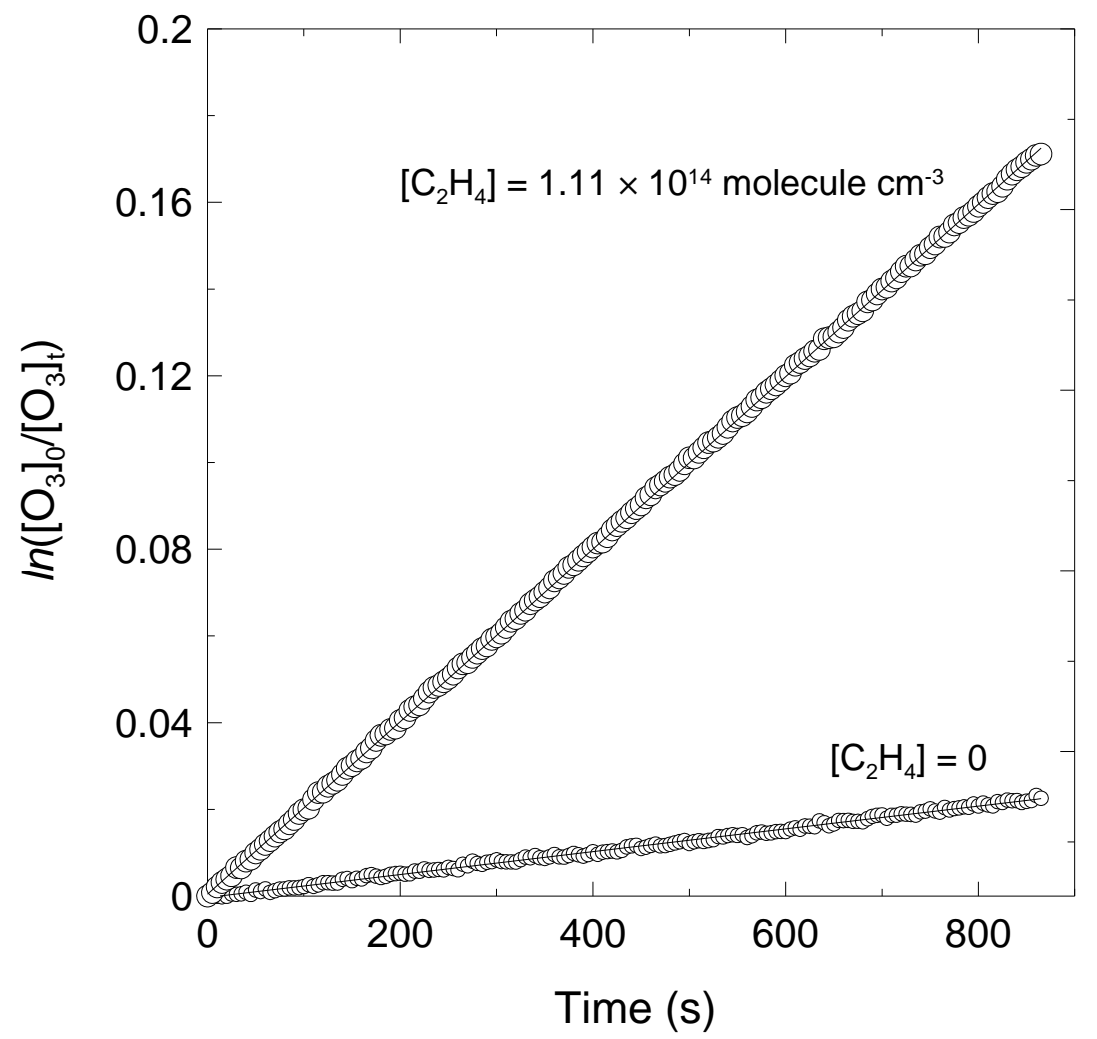

Fig. 1. Ozone loss in the absence and presence of $4.5 \mathrm{ppm}_{2} \mathrm{H}_{4}$ (i.e. $1.11 \times 10^{14}$ molecules $\left.\mathrm{cm}^{-3}\right)$. 


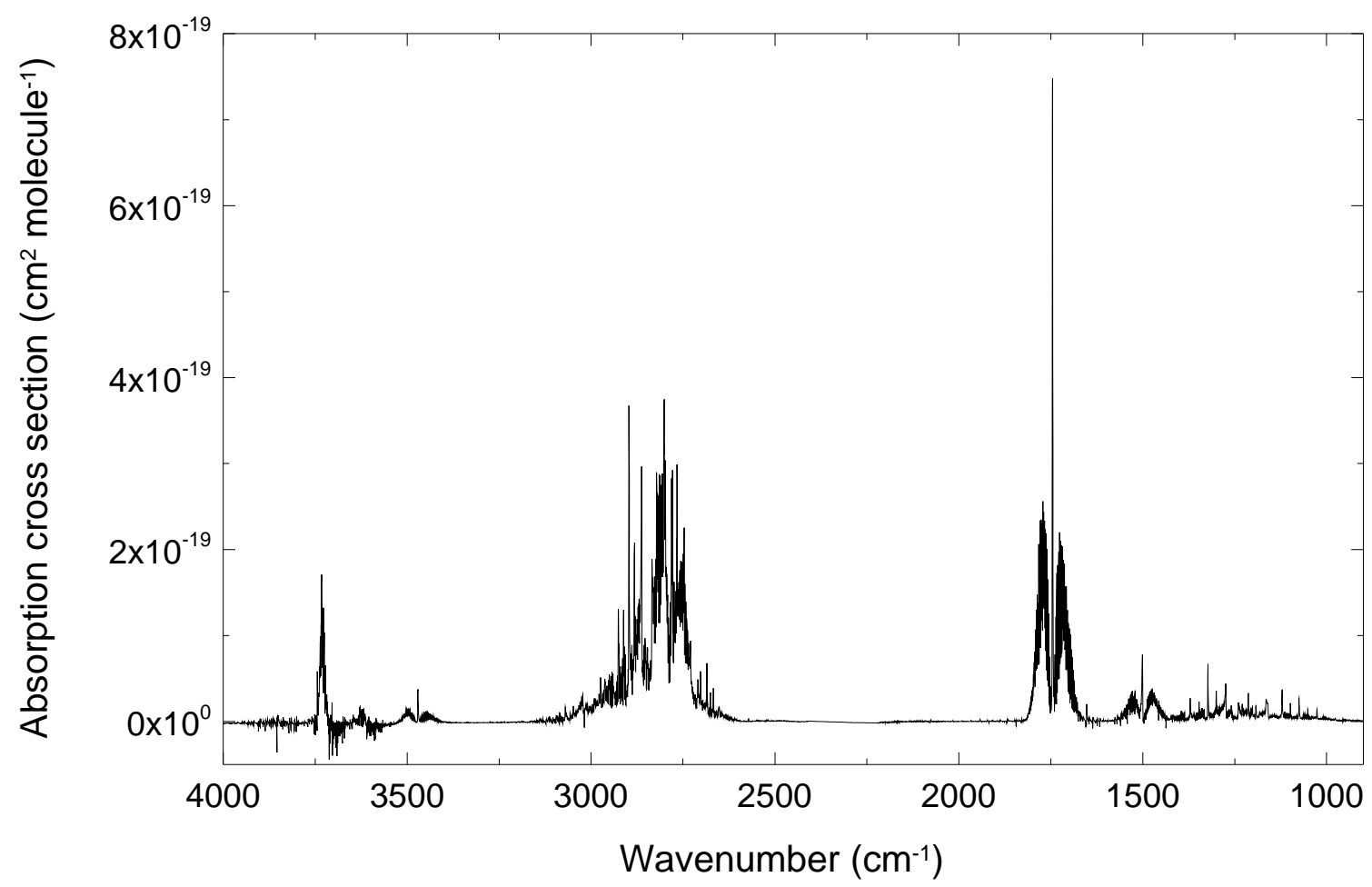

Fig. 2. Reference spectrum of $892.4 \mathrm{ppb}$ formaldehyde at $\mathrm{T}=296.5^{\circ} \mathrm{C}$ and $\mathrm{P}=1004.5 \mathrm{mbar}$ recorded at Euphore at a resolution of $1 \mathrm{~cm}^{-1}$. 


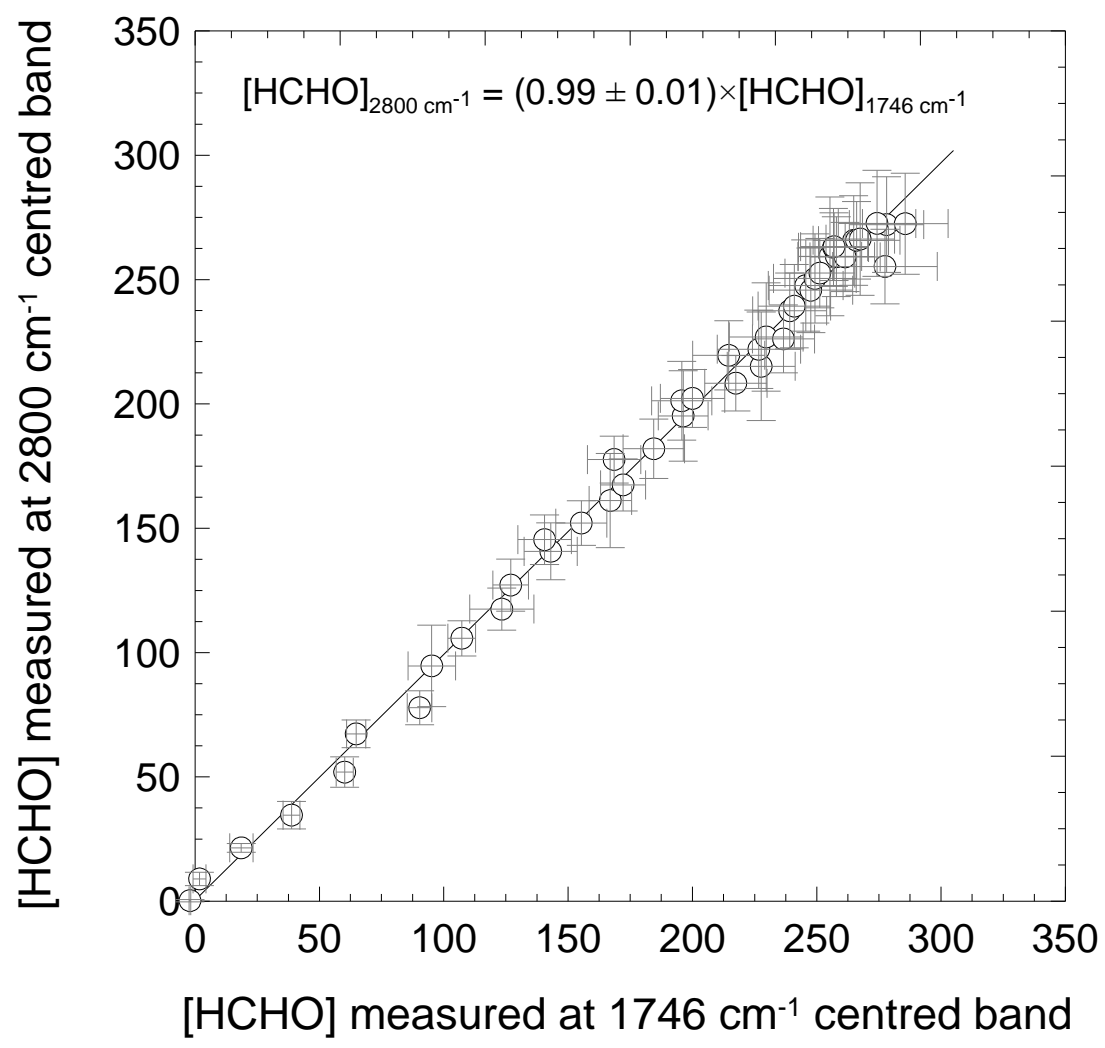

Fig. 3. Correlation between measurements performed with the $1660-1820 \mathrm{~cm}^{-1}$ band (centred at $1746 \mathrm{~cm}^{-1}$ ) and the $2600-3100 \mathrm{~cm}^{-1}$ band (centred at $2800 \mathrm{~cm}^{-1}$ ) 


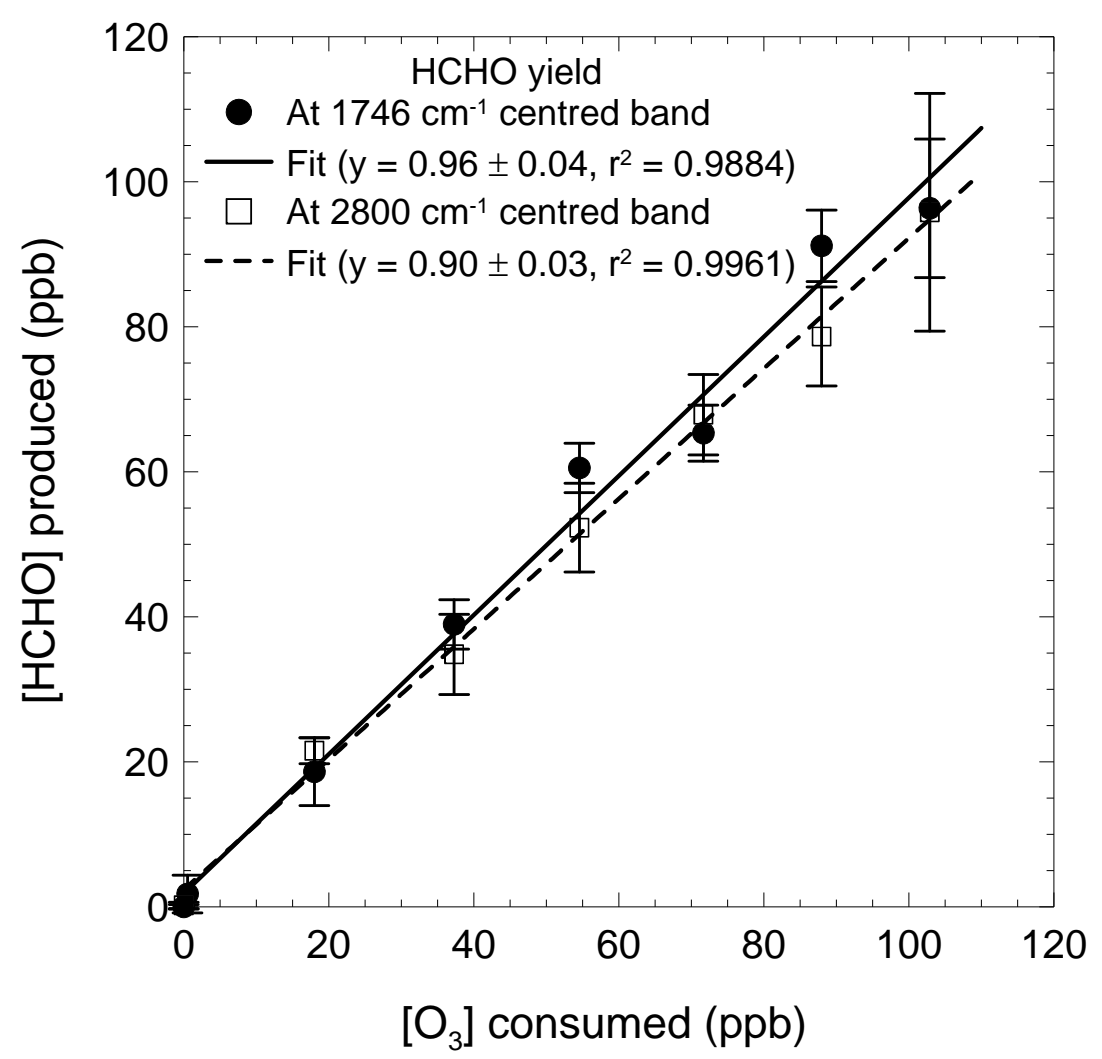

Fig. 4. $\mathrm{HCHO}$ formation yield from ozonolysis of ethene obtained from the $1746 \mathrm{~cm}^{-1}$ and $2800 \mathrm{~cm}^{-1}$ centred bands at early stage of the reaction. 


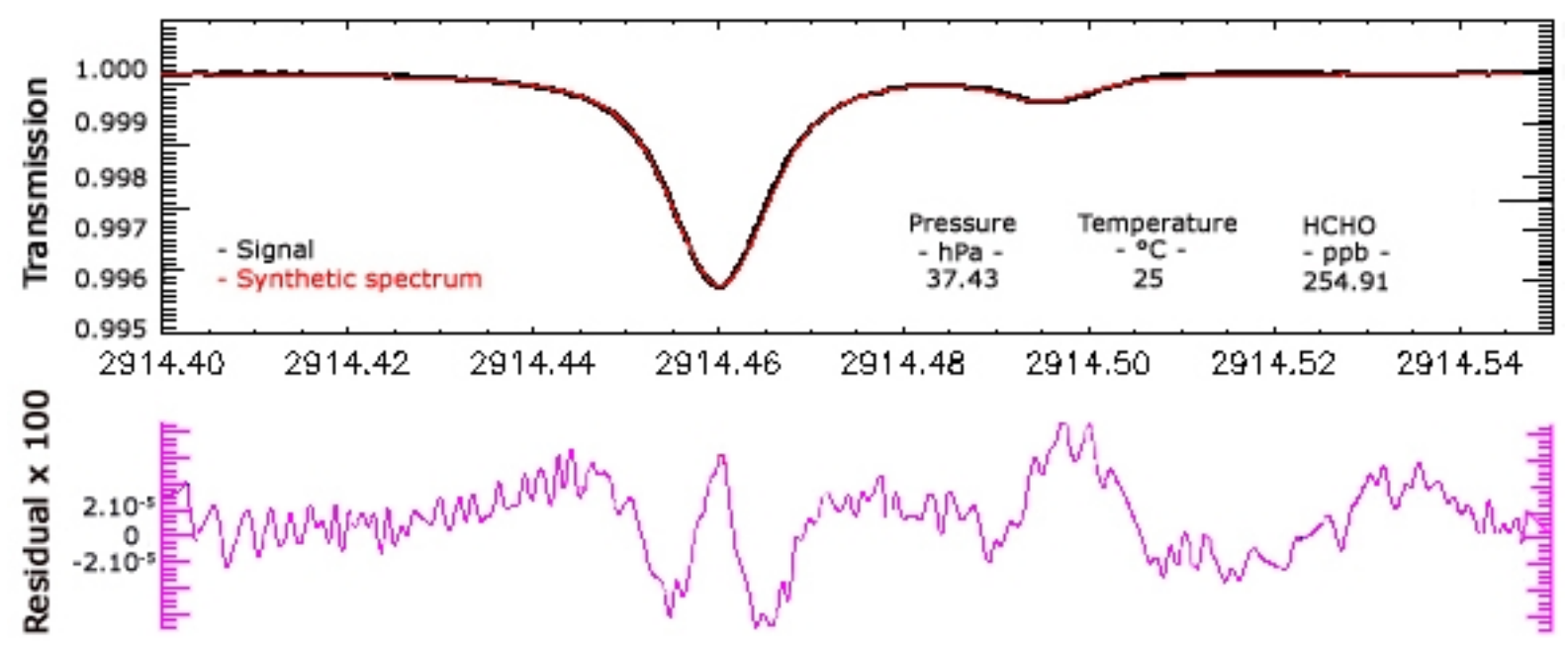

Fig. 5. Example of a spectral micro-window used to retrieve the HCHO line intensity $S$ at $2914.46 \mathrm{~cm}^{-1}$ by TDLAS. Top: The black line represents the experimental transmission spectrum and the red line the synthetic transmission spectrum. Bottom: The pink line represents the residual of the signal, i.e. the subtraction between the experimental and synthetic signals. Statistical precision on this fit is $1.5 \%(1 \sigma)$. 


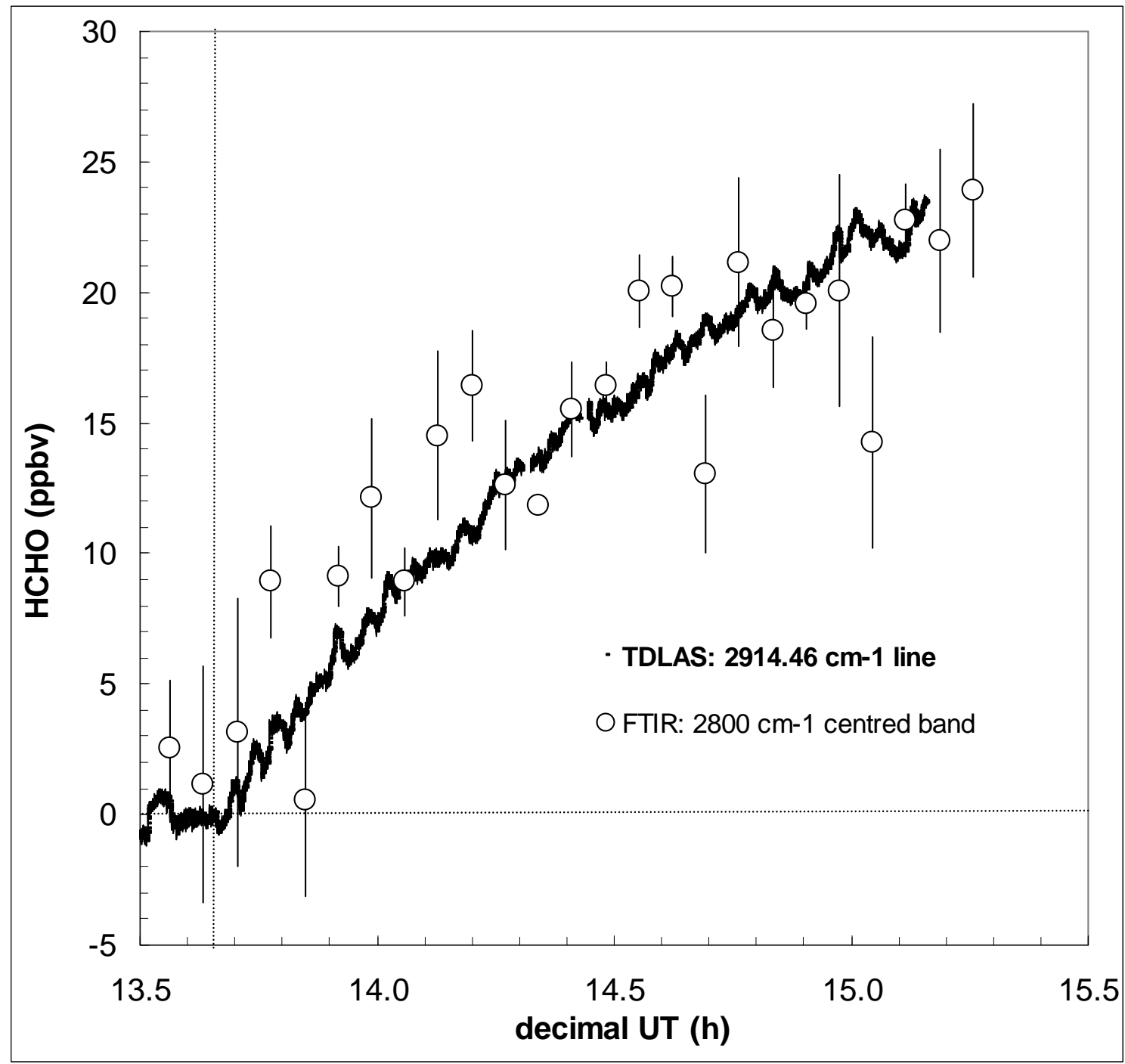

Fig. 6. Concentration time-profiles of formaldehyde using TDLAS and FTIR measurements during ethene ozonolysis reaction, with initial volume mixing ratios of 219.0 $\pm 0.1 \mathrm{ppb}_{3}$ and $681 \pm 30 \mathrm{ppb} \mathrm{C}_{2} \mathrm{H}_{4}$. Error bars are labelled for each measurement point and represent only $1 \sigma$ precision. The horizontal and vertical dotted lines represent the zero $\mathrm{HCHO}$ concentration and the reactant mixing beginning $(13.66 \mathrm{~h})$, respectively. 


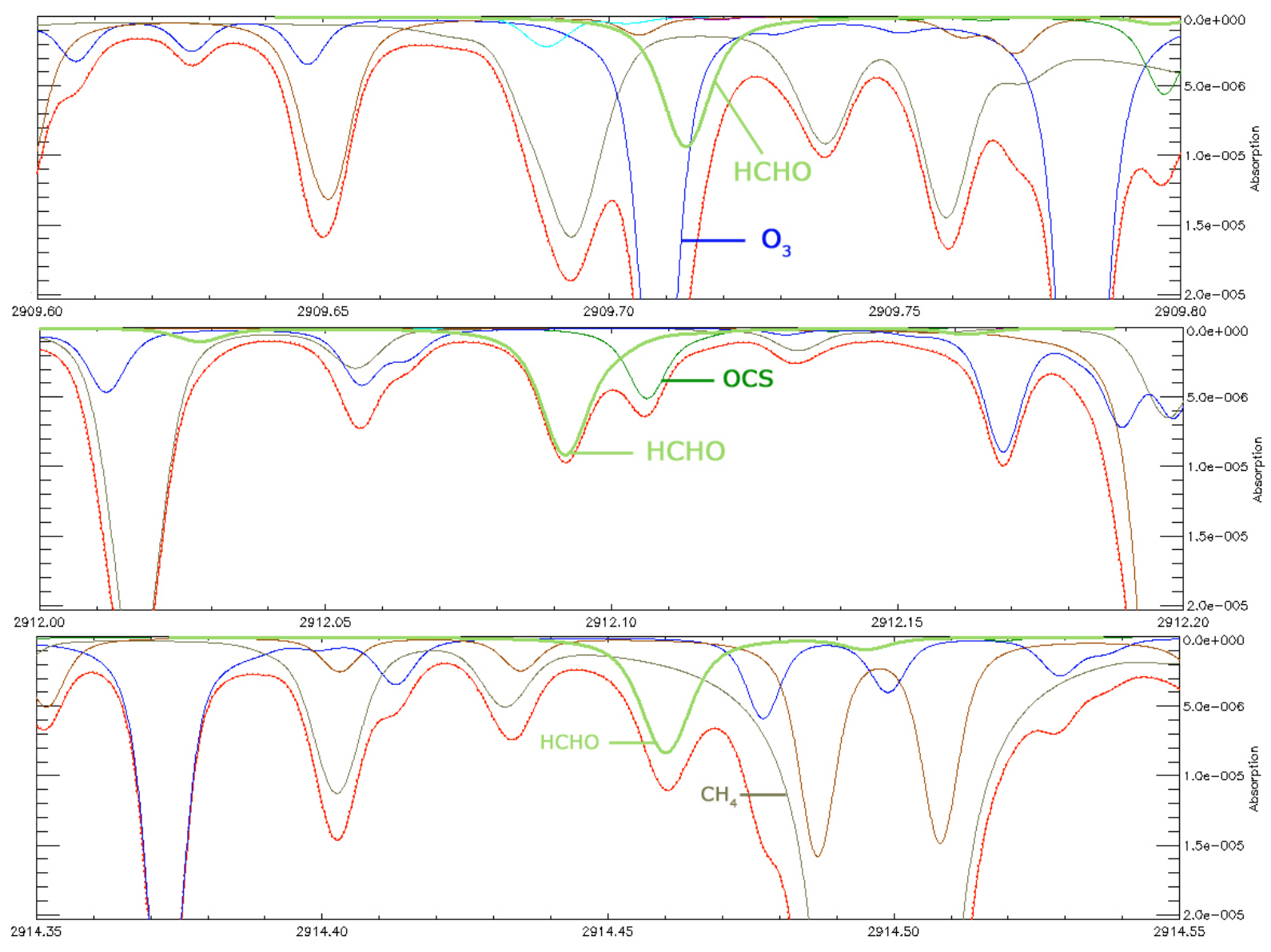

Fig. 7. Simulations of the transmission spectra at $25 \mathrm{~km}$ altitude, around $2909.71 \mathrm{~cm}^{-1}$ (top), $2912.09 \mathrm{~cm}^{-1}$ (middle) and $2914.46 \mathrm{~cm}^{-1}$ (bottom), considering a $431 \mathrm{~m}$ optical path (SPIRALE configuration) and based on HITRAN 2008 spectroscopic parameters (Rothman et al., 2009). The transmission spectra are color-coded (green: $\mathrm{HCHO}$, blue: $\mathrm{O}_{3}$, dark green: OCS, grey: $\mathrm{CH}_{4}$; brown: $\mathrm{NO}_{2}$, turquoise: $\mathrm{H}_{2} \mathrm{O}$ ) for each species and the red line indicates the total transmission. 

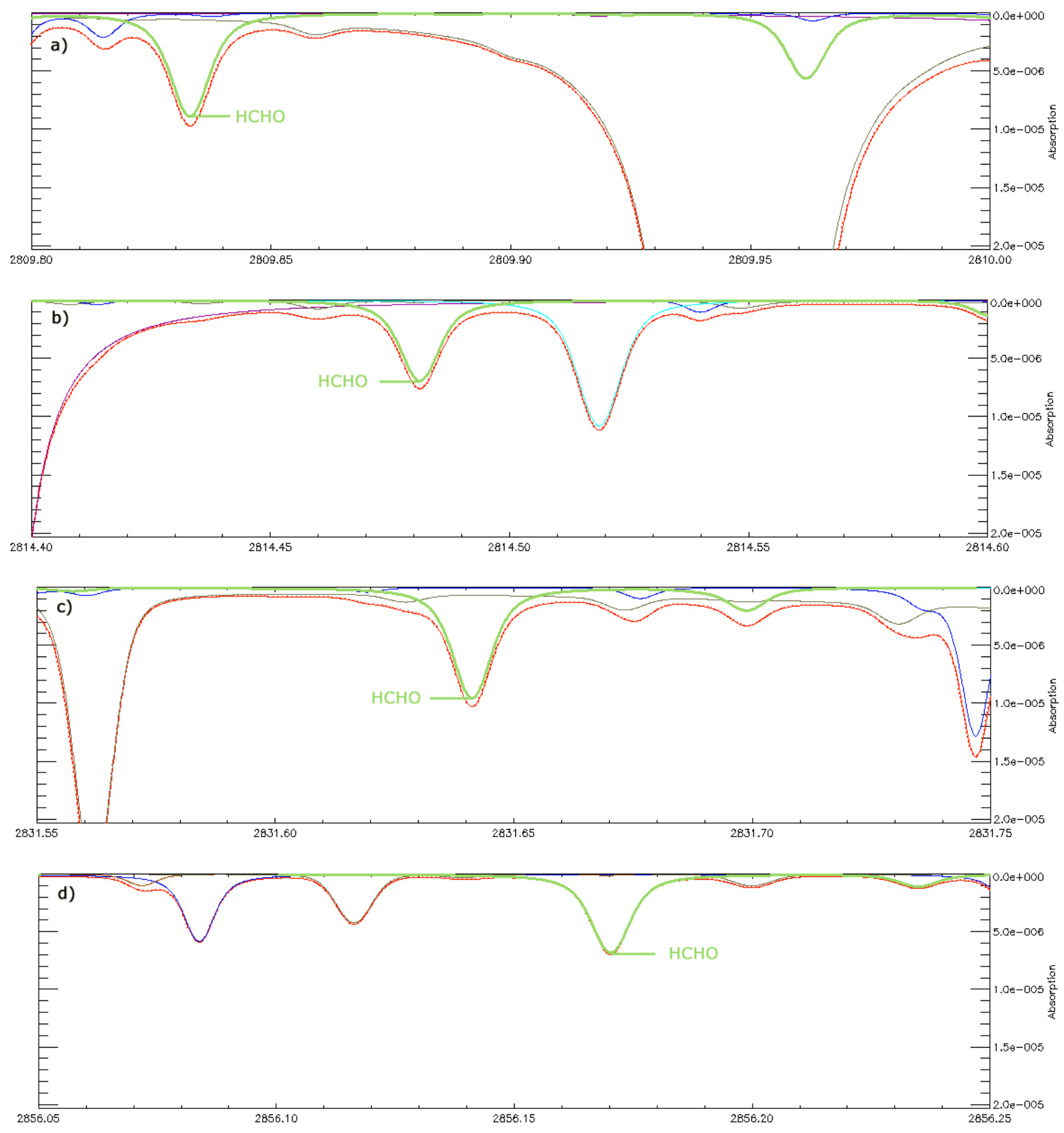

Fig. 8. Simulations of transmission spectra at $25 \mathrm{~km}$ altitude around: (a) $2809.83 \mathrm{~cm}^{-1}$, (b) $2814.48 \mathrm{~cm}^{-1}$, (c) $2831.64 \mathrm{~cm}^{-1}$, (d) $2856.17 \mathrm{~cm}^{-1}$, considering a $431 \mathrm{~m}$ optical path (SPIRALE configuration) and based on HITRAN 2008 spectroscopic parameters (Rothman et al., 2009). The transmission spectra are color-coded for each species (see Fig. 7 caption for detail) and the red line indicates the total transmission. 